Studia z Dziejów Średniowiecza, t. 24, 2020

\author{
Beata Możejko \\ (Uniwersytet Gdańsk) \\ https://orcid.org/0000-0002-0085-8686
}

\title{
O okolicznościach narodzin królewskich dzieci w świetle itinerarium Kazimierza Jagiellończyka i Elżbiety Rakuskiej
}

\author{
https://doi.org/10.26881/sds.2020.24.06
}

Keywords: family, Kazimierz Jagiellończyk, Elżbieta Rakuska, children, itinerary, conception and birth

10 lutego 1454 r. król Polski Kazimierz Jagiellończyk (urodzony w 1427 r.) zawarł związek małżeński z Elżbietą Rakuska (urodzoną około 1436/1437 r.), córką króla niemieckiego, czeskiego i węgierskiego Albrechta II Habsburga i Elżbiety Luksemburskiej. Opis uroczystości zaślubin zawdzięczamy Janowi Długoszowi. Powitanie narzeczonej miało miejsce 9 lutego 1454 r. Król w towarzystwie swej matki Zofii, dostojników kościelnych i świeckich, książąt: raciborskiego Wacława, oświęcimskich Wacława i Jana przyją „radośnie i wesoło swoją nową narzeczona, królewską dziewicę Elżbietę". Polski monarcha wystapił w kosztownych szatach, konie zaś okryte były aksamitem przetykanym złotymi nićmi. Wartość stroju królewskiego, siodła, uprzęży, strzemion i wędzidła wyceniono na 40 tys. florenów ${ }^{1}$. Przepych ten miało naśladować otoczenie króla, które okryło siebie, służbę i konie wspaniałymi szatami „złotem i purpurą. Plany ukazania splendoru władzy nie

\footnotetext{
1 Długosz, lib. 12 (1445-1461), s. 178; por. ks. 12 (1445-1461), s. 201; U. Borkowska, Dynastia Jagiellonów w Polsce, Warszawa 2011, s. 252, gdzie starsza literatura.
} 
do końca się powiodły, ponieważ akurat tego dnia padał bardzo obfity deszcz i szaty uległy w znacznej części zniszczeniu ${ }^{2}$.

Nie wiemy, jak narzeczeni zareagowali na swój widok. Kronikarz zapisał jedynie, iż po podaniu sobie rak (pierwszy kontakt fizyczny) panna Elżbieta została „przyjęta do powozu przez królową Zofię" ${ }^{3}$. Następnie przy dźwiękach trąb narzeczoną wprowadzono do zamku krakowskiego, jak jednak podkreślał kronikarz, stało się to dopiero pod wieczór, bo trudno było przedrzeć się przez tłum, w kościele witali ją kardynał i biskup krakowski Zbigniew oraz prałaci i kanonicy. Po modlitwie i złożeniu darów udano się na zamek ${ }^{4}$, gdzie królewna spędziła noc, a następnego dnia rano (10 lutego) odbył się ślub. Samej uroczystości towarzyszył spór, kto ma go udzielić: kardynał i biskup krakowski Zbigniew Oleśnicki czy arcybiskup gnieźnieński Jan ze Sprowy. Wydaje się zastanawiające, że wcześniej nie uzgodniono takich szczegółów. Według Jana Długosza zgodę na udzielenie ślubu uzyskał brat Jan Kapistran, ponieważ jednak nie znał języka polskiego i niemieckiego, ostatecznie ceremonię poprowadził kardynał Zbigniew Oleśnicki władajaccy oboma tymi językami. Po ślubie miała miejsce ceremonia namaszczenia i koronacja Elżbiety sprawowana przez arcybiskupa gnieźnieńskiego Jana ze Sprowy ${ }^{5}$. Uroczystości weselne

2 Długosz, lib. 12 (1445-1461), s. 178; ks. 12 (1445-1461), s. 201. Strój był $\mathrm{w}$ średniowieczu jednym z ważniejszych elementów manifestowania splendoru władzy. O polskich strojach ceremonialnych, w tym ślubnych, zob. K. Turska, Ubiór dworski w Polsce $w$ dobie pierwszych Jagiellonów, Ossolineum 1987, s. 20-28, gdzie co prawda brak odniesienia do stroju Kazimierza Jagiellończyka (pytanie, czy był to strój ślubny, czy tylko powitalny i uległ zniszczeniu na skutek deszczu). Autorka wspomniała natomiast o stroju ślubnym Ludwika Jagiellończyka, króla Węgier (syn Władysława Jagiellończyka i wnuk Kazimierza). Strój ten miał być uszyty ze srebrzystego brokatu i naśladować krój „houppelande”. O budowaniu splendoru władzy poprzez ubiór zob. też M. Molenda, Splendide vestitus. O znaczeniu ubiorów na królewskim dworze Jagiellonów w latach 1447-1572, Kraków 2012.

3 Długosz, lib. 12 (1445-1461), s. 178; ks. 12 (1445-1461), s. 201; B. Czwojdrak, Zofia Holszańska, Studium o dworze w późnośredniowiecznej Polsce, Warszawa 2012, s. 69.

4 Długosz, lib. 12 (1445-1461), s. 178-179; ks. 12 (1445-1461), s. 201-202.

5 Długosz, lib 12 (1445-1461), s. 179-180; ks. 12 (1445-1461), s. 202-203. Wedle innego źródła ślubu udzielał kardynał Zbigniew Oleśnicki, koronacji Elżbiety dokonał zaś arcybiskup gnieźnieński Jan ze Sprowy, zob. Kalendarz katedry krakowskiej [w:] MPH s.n., t. 5: Najdawniejsze roczniki krakowskie i kalendarz, wyd. Z. Kozłowska-Budkowa, Warszawa 1978, s. 123-124, w przyp. 82 wydawcy jednak wyjaśnienie, że ślubu udzielił Jan Kapistran (z odwołaniem do Rozbioru krytycznego, zob. niżej). W kolejnym źródle, w Rocznikach Jana z Targowiska, podobnie 
trwały 8 dni. Jak twierdził Jan Długosz, towarzyszacy królowej dostojnicy węgierscy, czescy i austriaccy byli codziennie zaopatrywani we wszystko, co potrzebne, czyli pozostawali na utrzymaniu polskiego monarchy. 18 lutego 1454 r., jak dalej relacjonował Długosz, goście obdarowani wspaniałymi darami, podziękowawszy w podziwu godny sposób Kazimierzowi, wrócili do siebie ${ }^{6}$.

Kazimierz Jagiellończyk i Elżbieta doczekali się 13 potomków, w tym 7 córek ( 2 z nich, obie o imieniu Elżbieta, zmarły we wczesnym dzieciństwie) oraz 6 synów. W sumie zatem dorosłego wieku dożyło 11 dzieci $^{7}$. Wiadomo, że Elżbieta przez lata towarzyszyła Kazimierzowi Jagiellończykowi w podróżach. Dzięki dotychczasowym badaniom znane są itineraria tego króla i jego małżonki ${ }^{8}$. Jest

jak u Długosza, mowa o sporze (ceremonialnym) pomiędzy wspomnianymi najwyższymi godnością polskimi duchownymi. Autor zapiski przywołuje jednak informację z pieśni (tekst pieśni nie został podany) Jędrzeja (Andrzeja) Strzesicha z Krakowa, ułożonej z okazji koronacji Elżbiety, wedle której zwaśnione strony pogodził Jan Kapistran, zob. Rocznik Jana z Targowiska, wyd. E. Kalitowski [w:] MPH, t. 3, Lwów 1878, s. 235; zob. też Rozbiór krytyczny „Annalium Poloniae Jana Dtugosza”, oprac. St. Gawęda, K. Pieradzka, J. Radziszewska, pod kierunkiem J. Dąbrowskiego, Wrocław-Kraków 1965, s. 61 z odwołaniem do tych dwóch, obok Długosza, źródeł; por. Z. Wdowiszewski, Genealogia Jagiellonów i Domu Wazów w Polsce, Warszawa 1968, s. 96 (na podstawie Jana Długosza i Jana z Targowiska; por. też U. Borkowska, Królewskie zaślubiny, narodziny i chrzest [w:] Images potestatis. Rytuaty, symbole i konteksty fabularne wtadzy zwierzchniej. Polska X-XV w., red. J. Banaszkiewicz, s. 77, wedle której małżeństwo miał pobłogosławić Jan Kapistran, ale ponieważ nie znał języka nowożeńców, wyręczył go Zbigniew Oleśnicki władający też językiem niemieckim; podobnie zob. idem, Dynastia..., s. 250 (tylko na podstawie Długosza).

6 Długosz, lib. 12 (1445-1461), s. 179-180; ks. 12 (1445-1461), s. 202-203.

7 Mimo wszystko było to pewnym wyjątkiem nawet w rodzinach królewskich, które z racji wysokiego urodzenia i majątku mogły, w porównaniu ze zwykłymi rodzinami, zapewnić przecież lepszą opiekę potomstwu, a mimo to nie udawało się uchronić dzieci przed przedwczesną śmiercia, np. Fryderyk III Habsburg i jego małżonka Eleonora Portugalska (małżeństwo zawarte w 1452 r., królowa zmarła w 1467 r.) mieli piątkę dzieci, z których troje zmarło, nie dożywszy nawet roku. Zob. też ostatnio uwagi R. Bartlett, Blood royal. Dynastic politics in medieval Europe, Cambridge 2020, s. 52-83.

8 T. Rombek, Otoczenie królowej Elżbiety Rakuszanki (1454-1505), Katowice 2012, mps rozprawy doktorskiej obronionej pod kierunkiem prof. J. Sperki, zob. Aneks nr 4: Itinerarium królowej Elżbiety Rakuszanki (1454-1505) (dalej: T. Rombek, Otoczenie, Aneks Itinerarium); G. Rutkowska, Itinerarium króla Kazimierza Jagiellończyka 1440-1492, Warszawa 2014, gdzie zebrana literatura poświęcona m.in. itinerariom; zob. też uwagi eadem, Podróże polskich królowych w XV wieku [w:] Samotrzeć, w kompanii czy z orszakiem? Społeczne aspekty podróżowania $w$ średniowieczu $i$ w czasach nowożytnych, red. M. Saczyńska, E. Wółkiewicz, 
to zatem dobry punkt wyjścia do prześledzenia nie tylko podróży monarszych, ale w tym konkretnym wypadku chcemy zwrócić uwagę na związek pomiędzy itinerarium a poczęciem i narodzinami królewskich potomków ${ }^{9}$.

Wiadomo, że już dwa dni po zakończeniu uroczystości weselnych króla Kazimierza Jagiellończyka pochłonęły sprawy pruskie i 20 lutego 1454 r. przyjał w Krakowie poselstwo Związku Pruskiego ${ }^{10}$. Kazimierz Jagiellończyk po negocjacjach z pruskim poselstwem opuścił 25 marca Kraków, gdzie zostawił matkę i żonę (czyli zaledwie kilka tygodni po ślubie) i 4 kwietnia $1454 \mathrm{r}$. zjawił się w Brześciu Litewskim ${ }^{11}$. Święta Wielkanocy (21 kwietnia) spędził w Sandomierzu, „bo matka i żona przybyły tam do niego"12. Obecność po ślubie pary królewskiej w Krakowie, później zaś w Sandomierzu, nie wpłynęła jednak na powołanie na świat potomstwa. Nie możemy jednak zapominać, że z punktu widzenia nakazów Kościoła nie był to czas sprzyjający współżyciu seksualnemu. Już bowiem od 6 marca do 18 kwietnia $1454 \mathrm{r}$. przypadał okres Wielkiego Postu, kiedy Kościół zalecał nie tylko wstrzemięźliwość od jedzenia, ale też od współżycia seksualnego ${ }^{13}$.

Warszawa 2012, s. 175-197; por. R. Krajniak, Itineraria Jagiellonów. Uwagi i uzupetnienia do kolejnych tomów serii, „Klio. Czasopismo Poświęcone Dziejom Polski i Powszechnym" 2018, t. 44 (1), s. 149-167, komentarze odnośnie do opracowania Rutkowskiej (s. 151-156), z tym że już na samym początku Krajniak zastrzegł: „chciałbym zwrócić uwagę na źródła, które jednak umknęły autorce. Wyraźnie pragnę jednak zaznaczyć, że nie przynoszą one nowych, nieznanych Rutkowskiej miejsc pobytu Kazimierza Jagiellończyka, a są jedynie owymi kopiami itd., których treść zazwyczaj autorka znała skądinąd”. Z kolei nadal w dużej mierze są aktualne postulaty badawcze zgłoszone przez P. Węcowskiego, Polskie itineraria średniowieczne i nowożytne. Przeglad badań i propozycje badawcze, SŹ 2000. t. 37, s. 13-48.

9 Zob. już ustalenia G. Rutkowskiej, Itineraria żon króla Wtadysława Jagietty, RH 1998, R. 64, 1998, s. 79-80 odnośnie do czasu i miejsca poczęcia synów Władysława Jagiełły i Zofii (chodzi o obu Kazimierzów); B. Czwojdrak, Zofia..., s. 27-29.

10 Długosz, lib. 12 (1445-1461), s. 180-198; ks. 12 (1445-1461), s. 203-223;

M. Biskup, Trzynastoletnia wojna $z$ Zakonem Krzyżackim 1454-1466, Warszawa 1967, s. 37-41.

11 Długosz, lib. 12 (1445-1461), s. 199; ks. 12 (1445-1461), s. 225; por. G. Rutkowska, Itinerarium..., s. 128-129.

12 Długosz, lib. 12 (1445-1461), s. 200; ks. 12 (1445-1461), s. 226; G. Rutkowska, Itinerarium..., s. 129; T. Rombek, Otoczenie, Aneks Itinerarium, s. 265; B. Czwojdrak, Zofia..., s. 69.

13 I. Skierska, Sabbatha sanctifices.. Dzień święty w średniowiecznej Polsce, Warszawa 2008, s. 53 (ale tu o Adwencie - czas pokuty, powstrzymywania się od zabaw i od współżycia seksualnego). 
Z kolei gdy małżonkowie spotkali się w Sandomierzu, był czas świąteczny (Wielkanocy). W czasie Świąt też nie można było płodzić - to grzech - według Stanisława ze Skarbimierza spłodzone dzieci w tym czasie mogły się okazać trędowate lub opętane ${ }^{14}$.

Po świętach król z żoną i matką udali się do Łęczycy na wyznaczony na 1 maja zjazd ze szlachtą ${ }^{15}$. Stąd Kazimierz Jagiellończyk udał się do Torunia, gdzie przebywał od 23 maja do 5 czerwca $1454 \mathrm{r}^{16}$ 26 maja dołączyła doń z Łęczycy królowa Elżbieta, podróżująca razem z teściowa. Małżonkowie nocowali w Ratuszu Staromiejskim ${ }^{17}$. Obie panie nie towarzyszyły Kazimierzowi Jagiellończykowi, gdy 5 czerwca 1454 r. udał się do Elblaga. Rezydowały w zamku w Nieszawie i raz po raz - jak twierdził Długosz - przyjeżdżały do Torunia na taneczne uroczystości ${ }^{18}$. Król powrócił do Torunia około 24 czerwca $^{19}$. Mimo toczącej się wojny także i on nie miał stronić od rozrywek i to nie tylko w świąteczne dni, ale też w powszednie. Krytycznie odnosił się do tego Jan Długosz, zarzucając królowi, że bawił się, „nie pamiętając o wykonaniu tego, czego się podjął", czyli prowadzenia działań wojennych ${ }^{20}$. Po kilkunastodniowym pobycie w Grudziądzu król od 27 lipca do 9 września ponownie pozostawał w Toruniu, wprawdzie zajmowały go sprawy wojenne ${ }^{21}$, ale 25 września zjawił się na jeden dzień w Nieszawie, gdzie - jak można się domyślać - cały czas przebywała jego małżonka ${ }^{22}$.

14 M. Dilemata, Dziecko w Polsce średniowiecznej, Poznań 2004, s. 58.

15 Długosz, lib. 12 (1445-1461), s. 200-201; ks. 12 (1445-1461), s. 226-227; G. Rutkowska, Itinerarium ..., s. 129 .

16 Długosz, lib. 12 (1445-1461), s. 201-202; ks. 12 (1445-1461), s. 227-228; M. Biskup, Historia Torunia. U schyłku średniowiecza $i$ w poczatkach odrodzenia (1454-1548), t. 2, Toruń 1992, s. 15-17; G. Rutkowska, Itinerarium..., s. 130.

17 M. Töppen, Die älteste Thorner Stadtchronik, „Zeitschrift des WestpreuBischen Geschichtsvereins" 1900, Bd. 42, s. 146; M. Biskup, Historia Torunia..., s. 15-17. O tej wizycie też W. Zawitkowska, W stużbie pierwszych Jagiellonów. Życie i działalność kanclerza Jana Taszki Koniecpolskiego, Kraków 2005, s. 260; T. Rombek, Otoczenie, Aneks Itinerarium, s. 265.

18 Długosz, lib. 12 (1445-1461), s. 204-206; ks. 12 (1445-1461), s. 231-232; B. Czwojdrak, Zofia..., s. 69.

19 M. Biskup, Historia Torunia..., s. 17; G. Rutkowska, Itinerarium..., s. 132.

20 Długosz, lib. 12 (1445-1461), s. 206; ks. 12 (1445-1461), s. 232. Kronikarz był duchownym i nie można zapominać o krytycznym stosunku Kościoła średniowiecznego do tańca, zob. S. Konarska-Zimnicka, Taniec w Polsce średniowiecznej. Świadectwo źródet pisanych, Kraków-Kielce 2009, s. 143 et seq.

21 G. Rutkowska, Itinerarium ..., s. 133.

22 Ibidem, s. 131. 
Od października 1454 r. królowa Elżbieta gościła na zamku w Sieradzu, w towarzystwie Doroty z Sienna, żony kanclerza Jana Taszki $\mathrm{z}$ Koniecpola ${ }^{23}$. Z mężem spotkała się dopiero w Łęczycy 2 lutego 1455 r., stamtąd razem udali się na Litwę ${ }^{24}$ i powrócili 15 maja do Piotrkowa, gdzie Kazimierz Jagiellończyk odbył zjazd ze stanami. Następnie w końcu (29) maja ${ }^{25}$ król skierował się do Łęczycy i innych mniejszych miejscowości. Elżbieta pozostawała w Piotrkowie, do którego król powrócił 24 czerwca. Ich pobyt w tym mieście trwał do 22 lipca 1455 r. $^{26}$

Biorąc pod uwage narodziny pierwszego potomka Elżbiety i Kazimierza Jagiellończyka, 1 marca 1456 r., przy cyklu około 9-miesięcznym (czyli w przybliżeniu 38-42 tygodni od zapłodnienia, czyli 280 dni +-20 dni) można przyjąć, że poczęcie pierworodnego miało miejsce między początkiem drugiego tygodnia maja a końcem maja 1455 r. Czas od 31 maja 1455 r. do 1 marca 1456 r. to modelowe 280 dni, jednak trzeba przyjąć owe 20 dni dodatkowe, co przesuwa datę poczęcia na mniej więcej połowę maja. Skoro jednak król był w Piotrkowie (pierwszy pobyt) do $28 / 29$ maja i ponownie spotkał się $\mathrm{z}$ żona $\mathrm{w}$ tym mieście dopiero 24 czerwca (drugi pobyt), to do poczęcia doszło najpóźniej w czasie tego pierwszego pobytu, czyli między $15 / 17$ a 29 maja 1455 r. Oczywiście nie możemy też wykluczyć, że pierwszy potomek tej pary został poczęty przed 17 maja w drodze (para wyjechała z Wilna 28 kwietnia), w grę wchodzą takie miejscowości, jak: Łuków - 9 maja (tu już mamy ponad 300 dni, uwzględniając te dodatkowo zakładane 20 dni), Kazimierz Dolny - 11 maja, Radom - 13 maja, Opoczno - 15 maja ${ }^{27}$. Nie możemy też oczywiście zupełnie wykluczyć, że dziecko urodziło się przed upływem zakładanych modelowych 280 dni i do poczęcia doszło w końcu czerwca, czyli podczas drugiego pobytu króla w Piotrkowie od 24 czerwca do 22 lipca. Współcześnie się przyjmuje, że do poczęcia pierwszego potomstwa dochodzi około pół roku od rozpoczęcia regularnego współżycia seksualnego ${ }^{28}$. W wypadku tej królewskiej pary upłynęło około 16 miesięcy,

23 Długosz, lib. 12 (1445-1461), s. 226; ks. 12 (1445-1461), s. 256; T. Rombek, Otoczenie, Aneks Itinerarium, s. 265; W. Zawitkowska, W stużbie..., s. 167.

24 Długosz, lib. 12 (1445-1461), s. 226; ks. 12 (1445-1461), s. 256; G. Rutkowska, Itinerarium..., s. 139; T. Rombek, Otoczenie, Aneks Itinerarium, s. 266.

25 Długosz, lib. 12 (1445-1461), s. 231; ks. 12 (1445-1461), s. 262 - że 17 maja; por. jednak inne źródła, że 15 maja, wymieniła je G. Rutkowska, Itinerarium ..., s. 141.

26 G. Rutkowska, Itinerarium..., s. 141.

27 Ibidem.

28 Zob. też T. Wiślicz, Upodobanie. Matżeństwo $i$ zwiazki nieformalne na wsi polskiej XVII-XVIII wieku, Wrocław 2012, s. 75. 
trzeba jedna pamiętać, że razem ze sobą byli właśnie nie dłużej niż około pół roku.

Od września do połowy grudnia 1455 r. król przebywał w Prusach, gdzie zajmowały go sprawy wojenne ${ }^{29}$, a Elżbieta 24 sierpnia $1455 \mathrm{r}$. była już w Krakowie ${ }^{30}$. Boże Narodzenie para królewska spędziła w Łęczycy, w styczniu 1456 r. małżonkowie udali się do Piotrkowa, gdzie król brał udział w zjeździe ze szlachta ${ }^{31}$. Można się domyślać, że w grudniu, właśnie przy okazji świąt Bożego Narodzenia, królowa pewna swego odmiennego stanu poinformowała o tym męża, zresztą wówczas (około 6. miesiąca) ciąża była już z pewnością widoczna także dla dworskiego otoczenia.

25 stycznia 1456 r. małżonkowie wrócili do Krakowa, gdzie wspólnie z królową Zofia spędzili czas zapustów i Wielkiego Postu ${ }^{32}$. Nietrudno oprzeć się wrażeniu, że król celowo teraz towarzyszył żonie będącej już w dość zaawansowanej ciąży. Wprawdzie 6 lutego Kazimierz Jagiellończyk przebywał w Niepołomicach, można się domyślać, iż brał udział w polowaniach ${ }^{33}$, ale już 8 lutego zjawił się z powrotem w Krakowie.

Według Jana Długosza pierwszy z synów Kazimierza Jagiellończyka - Władysław - urodził się w poniedziałek po niedzieli Oculi, to jest dnia pierwszego marca. „Po trzeciej godzinie w nocy królowa Polski Elżbieta urodziła bardzo piękne niemowlę, nader kształtne i zgrabne"34. Zdaniem astronomów, jak pisał dalej kronikarz, obraz nieba i położenia planet w godzinie jego urodzin wróżyły mu bardzo wielkie powodzenie i rządy nad wieloma ludami i królestwami ${ }^{35}$.

29 G. Rutkowska, Itinerarium..., s. 142 et. seq.

30 Korespondencja żupnika krakowskiego Mikołaja Serafina z lat 1437-1459, wyd. W. Bukowski, T. Płóciennik, A. Skolimowska, Kraków 2006, s. 154-155; T. Rombek, Otoczenie Aneks Itinerarium, s. 266.

31 Długosz, lib. 12 (1445-1461), s. 247; ks. 12 (1445-1461), s. 279; G. Rutkowska, Itinerarium..., s. 145-146.

32 G. Rutkowska, Itinerarium..., s. 146; B. Czwojdrak, Zofia..., s. 70 - królowa zawitała do Krakowa w lutym $1456 \mathrm{r}$.

33 G. Rutkowska, Itinerarium..., s. 146. O zamiłowaniu króla Kazimierza Jagiellończyka do łowów zob. A. Samsonowicz, Łowiectwo w Polsce Piastów i Jagiellonów, Warszawa 2011, s. 369-372.

34 Długosz, lib. 12 (1445-1461), s. 250; ks. 12 (1445-1461), s. 283; por. Z. Wdowiszewski, Genealogia Jagiellonów..., s. 166.

35 Długosz, lib. 12 (1445-1461), s. 250; ks. 12 (1445-1461), s. 283. O horoskopach dla synów Kazimierza Jagiellończyka zob. S. Konarska-Zimnicka, „Wenus pania roku, Mars towarzyszem...”. Astrologia w Krakowie XV i poczatku XVI wieku, Kielce 2018, s. 351. 
Dodajmy w tym miejscu, że pisząc tylko o tym dziecku, pierworodnym synu Elżbiety i króla Kazimierza Jagiellończyka, kronikarz poświęcił uwagę jego wyglądowi oraz układowi planet towarzyszących jego urodzinom. Mały królewicz został ochrzczony przez biskupa krakowskiego Tomasza Strzempińskiego 4 kwietnia 1456 r., czyli już jako miesięczne niemowlę, otrzymujacc - jak podkreślał Długosz - imię po dziadku ${ }^{36}$. W chrzcinach miała uczestniczyć tė̇ królowa Zofia ${ }^{37}$.

Czekanie z chrzcinami aż miesiąc było swego rodzaju ewenementem, w innych rodzinach królewskich chrztu dokonywano 2-4 dni po narodzeniu ${ }^{38}$. O przesunięciu o miesiąc chrztu pierworodnego potomka Elżbiety i Kazimierza Jagiellończyka mogły zadecydować dwie sprawy. Po pierwsze chłopiec urodził się w czasie Wielkiego Postu, gdy choćby ze względów nakazów religijnych nie można było uczcić chrzcin na przykład jakimś specjalnym posiłkiem, ucztowaniem i radowaniem się. Wielkanoc w $1456 \mathrm{r}$. przypadła 28 marca, chrzciny zaś tydzień później, w niedzielę 4 kwietnia. Po wtóre nie możemy wykluczyć, że czekano, by w uroczystościach mogła wziąć matka Władysława, królowa Elżbieta. Jak wiadomo, kobieta po urodzeniu dziecka nie mogła bez wywodu (oczyszczenia) przekroczyć progu kościoła. Położnicy zalecano pozostawanie przez 6 tygodni w łóżku, zakazywano używania jedwabnych kołder, czepców, poduszek ${ }^{39}$. Jeśli rzeczywiście czekano z chrzcinami pierworodnego syna, aż Elżbieta będzie mogła wziąć udział w tych uroczystościach - może to świadczyć o uczuciu i szacunku, jakim

36 Długosz, lib. 12 (1445-1461), s. 250; ks. 12 (1445-1461), s. 283; Z. Wdowiszewski, Genealogia Jagiellonów..., s. 166. O ceremoniach chrzcin Jagiellonów (ogólnie) zob. U. Borkowska, Dynastia..., s. 255, gdzie starsza literatura.

37 B. Czwojdrak, Zofia..., s. 70.

38 Zob. N. Orme, Medieval Children, Yale 2001, s. 25, gdzie informacja, że w XV w. w angielskich rodzinach królewskich dzieci były chrzczone po 2-4 dniach od urodzenia. Podobnie było we Francji: Ludwik XI, syn Karola VII Walezjusza i Marii Andegaweńskiej, urodził się około trzeciej popołudniu 3 lipca $1423 \mathrm{r}$. w pałacu biskupim w Bourges, nieopodal katedry Świętego Stefana. Jego chrzest miał miejsce już następnego dnia właśnie w tej katedrze, nabożeństwo odprawił książę, biskup Laon, Guillaume de Champeaux, ojcami chrzestnymi byli kanclerz Francji oraz 14-letni Jan, książę d'Alençon, przy chrzcielnicy dziecko trzymała Katarzyna de l'Isle Bouchard, hrabina Tonnére, zob. P.M. Kendall, Ludwik XI, Warszawa 1976, s. 27-28.

39 M. Delimata, Dziecko w Polsce średniowiecznej..., s. 67. Wojciech Jastrzębiec w statutach z 1423 r. zalecał małżonkom wstrzymywanie się od współżycia po porodzie. 
król darzył swoją małżonkę i o tym, że to on zadecydował o terminie chrztu. W wypadku małego Władysława Jagiellończyka nie wiadomo nic o rodzicach chrzestnych.

25 kwietnia 1456 r., czyli gdy Władysław miał około 2 miesięcy, król Kazimierz Jagiellończyk po uporządkowaniu i załatwieniu spraw publicznych wyjechał z żona z Krakowa ${ }^{40}$. Ich synek został najpewniej na Wawelu pod opieka babki. Według Małgorzaty Wilskiej małe dzieci króla Kazimierza Jagiellończyka - gdy nie zachodziły wyjątkowe okoliczności - pozostawały zazwyczaj na Wawelu, ale starsze były właczone w system objazdów ${ }^{41}$. Jak zdaje się wynikać z dalszych naszych dociekań, małżonkowie zabierali jednak w podróż już nawet te małe dzieci. Po wyjeździe z Krakowa w kwietniu 1456 r. para królewska nie rozstawała się ze sobą przez prawie rok. Elżbieta towarzyszyła mężowi podczas wykonywania przez niego rządów w Wielkopolsce, ziemi łęczycko-sieradzkiej, w trakcie pobytu w Toruniu i razem z nim wróciła w końcu września do Krakowa ${ }^{42}$. W początkach października 1456 r., ze względu na szerzącą się zarazę ${ }^{43}$, para królewska i królowa Zofia (a więc chyba w tym wyjątkowym wypadku też i malutki Władysław) opuścili Kraków i udali się na Litwę. Boże Narodzenie para królewska spędziła w Wilnie, przebywając tam aż do lutego $1457 \mathrm{r.}^{44}$

Biorąc pod uwagę, że kolejne dziecko Elżbiety i Kazimierza Jagiellończyka przyszło na świat 21 września 1457 r., musiało zostać poczęte w Wilnie w styczniu lub na początku lutego tego roku. Dodajmy, iż od pierwszego porodu do ponownej ciąży minęło około 9 miesięcy. 16 marca 1457 r. Kazimierz Jagiellończyk z żoną i matką dotarł do Piotrkowa ${ }^{45}$. Królowa była już wówczas w 2-3 miesiącu ciąży i nie towarzyszyła Kazimierzowi Jagiellończykowi w dalszej jego podróży.

40 Długosz, lib. 12 (1445-1461), s. 251; ks. 12 (1445-1461), s. 283; T. Rombek, Otoczenie, Aneks Itinerarium, s. 266; G. Rutkowska, Itinerarium..., s. 149.

41 M. Wilska, Dwór i kultura dworska [w:] Kultura Polski średniowiecznej $X I V-X V w .$, red. B. Geremek, Warszawa 1997, s. 83.

42 T. Rombek, Otoczenie, Aneks Itinerarium, s. 266-267; G. Rutkowska, Itinerarium..., s. 149-151.

43 B. Czwojdrak, Zofia..., s. 70.

44 T. Rombek, Otoczenie, Aneks Itinerarium, s. 267; G. Rutkowska, Itinerarium..., s. $155-156$.

45 G. Rutkowska, Itinerarium..., s. 156. 
21 września 1457 r. królowa Elżbieta urodziła - ponownie w Krakowie na Wawelu - córkę, która na chrzcie w katedrze krakowskiej otrzymała imię Jadwiga ${ }^{46}$, co było zapewne upamiętnieniem królowej Jadwigi Andegaweńskiej. Nie wiadomo, w jakim czasie po urodzeniu królewska córka została ochrzczona i kim byli rodzice chrzestni ani nawet, kto ja ochrzcił - Jan Długosz był w tym wypadku bardzo lakoniczny. W czasie gdy Elżbieta rodziła drugie dziecko, Kazimierz był w Łęczycy na zjeździe ze szlachta (20-26 września), następnie kontynuował objazd kraju ${ }^{47}$. Nieobecność króla przy żonie była spowodowana oczywiście sytuacja polityczna, jego zaangażowaniem w wojnę - nie faktem, że urodziła się dziewczynka, a nie chłopiec. W końcu listopada obie królowe, Elżbieta i Zofia, wyjechały naprzeciw Kazimierzowi do Piotrkowa, gdzie od 25 listopada do 6 grudnia $1457 \mathrm{r}$. miał miejsce jego zjazd ze szlachta ${ }^{48}$. Najpewniej podróżowały z królewskimi dziećmi, a Kazimierz miał okazję w Piotrkowie po raz pierwszy zobaczyć nowo narodzoną córkę. Przemawiają za tym dalsze wypadki - z Piotrkowa para królewska, w towarzystwie królowej Zofii, dotarła bowiem 16 grudnia do Sandomierza ${ }^{49}$, gdzie król pozostawił żonę z częścią bagażu ${ }^{50}$. Właśnie sformułowanie o bagażu może oznaczać, że podróżowano także z dwójka dzieci i być może ze względu na nie królowa zaniechała dalszej podróży z mężem.

Boże Narodzenie 1457 r. Kazimierz spędził w Nowym Korczynie - wiadomo, że w towarzystwie matki, królowej Zofii ${ }^{51}$. O obecności Elżbiety w tym miejscu źródła milcza - albo była jeszcze w Sandomierzu ${ }^{52}$, albo udała się wprost do Krakowa. W każdym razie spotkała się z mężem najpóźniej wówczas, gdy monarcha 29 grudnia przybył do Krakowa, zostając tam do 5 stycznia 1458 r. $^{53}$

46 Długosz, lib. 12 (1445-1461), s. 286; ks. 12 (1445-1461), s. 322; Z. Wdowiszewski, Genealogia Jagiellonów..., s. 98. Elżbiecie miała towarzyszyć królowa Zofia, zob. B. Czwojdrak, Zofia..., s. 70.

47 G. Rutkowska, Itinerarium..., s, 156-163.

48 Długosz, lib. 12 (1445-1461), s. 291-292; ks. 12 (1445-1461), s. 328; T. Rombek, Otoczenie, Aneks Itinerarium, s. 267; G. Rutkowska, Itinerarium..., s. 161-162; B. Czwojdrak, Zofia..., s. 70.

49 Tak B. Czwojdrak, Zofia..., s. 70, przyp. 84.

50 Długosz, lib. 12 (1445-1461), s. 293; ks. 12 (1445-1461), s. 330.

51 Długosz, lib. 12 (1445-1461), s. 295; ks. 12 (1445-1461), s. 332; G. Rutkowska, Itinerarium..., s. 162.

52 T. Rombek, Otoczenie, Aneks Itinerarium, s. 267.

53 Długosz, lib. 12 (1445-1461), s. 295; ks. 12 (1445-1461), s. 332. 
Domysł o rozstaniu się pary królewskiej w połowie grudnia $1457 \mathrm{r}$. z powodu dzieci (nie wchodźmy, czy jakaś ich choroba, czy zmęczenie) potwierdza także fakt, że z początkiem następnego roku (5 stycznia) Kazimierz i Elżbieta wyruszyli na Litwę, w Trokach byli 24 lutego 1458 r. ${ }^{54}$ i chyba właśnie w trasie do Trok, w połowie lutego, zostało poczęte kolejne dziecko, urodzone 3 października $1458 \mathrm{r}$. Ponownie miała zatem miejsce sytuacja „ciąża po ciąży”, poprzednie rozwiązanie miało miejsce 21 września 1457 r., a już w lutym 1458 r. - czyli po 5 miesiaccach przerwy - królowa była brzemienna. Para królewska spędziła na Litwie całą zimę i początek wiosny, także Wielkanoc, która tamtego roku przypadała 2 kwietnia ${ }^{55}$. Następnie król aż do później jesieni zajmował się sprawami związanymi z toczącą się wojną i królowa Elżbieta 3 października 1458 r., „o świcie, z brzaskiem zorzy porannej", urodziła drugiego syna, kiedy król przebywał w obozie wojsk polskich i związkowych pod Malborkiem ${ }^{56}$. W Krakowie przebywała wówczas królowa Zofia ${ }^{57}$, wspomagając synową. Monarcha przyjechał do Krakowa 30 października, a kilka dni później, 5 listopada, polecił biskupowi Tomaszowi ochrzcić już ponadmiesięcznego Kazimierza ${ }^{58}$. W następnych dniach uroczyście obchodzono chrzciny, imię syna oczywiście nawiązywało do imienia ojca. Król z żoną opuścili Kraków 19 grudnia (mały królewicz miał ponad dwa miesiące) i udali się do Sandomierza, gdzie spędzili święta Bożego Narodzenia (król był w Sandomierzu do 10 stycznia $1459 \mathrm{r}^{59}$ ). Mamy tu zatem po raz kolejny bardzo podobna sytuację: przy Władysławie, Jadwidze i Kazimierzu, para królewska około 2-3 miesięcy po urodzinach potomka wspólnie ruszała w trasę.

Kazimierz Jagiellończyk po 10 stycznia 1459 r. wyjechał na zjazd do Piotrkowa, żonę wysłał zaś na Litwę, dokąd sam skierował się w lutym $1459 \mathrm{r}$. Małżonkowie spędzili tu razem resztę zimy i wiosnę (w tym Wielkanoc 25 marca). Właśnie na Litwie zostało poczęte kolejne dziecko, wiadomo bowiem, że urodziło się

54 G. Rutkowska, Itinerarium..., s. 162-163.

55 Ibidem, s. 164.

56 Długosz, lib. 12 (1445-1461), s. 311-312; ks. 12 (1445-1461), s. 350; Z. Wdowiszewski, Genealogia Jagiellonów..., s. 100; G. Rutkowska, Itinerarium..., s. 167.

57 B. Czwojdrak, Zofia..., s. 71.

58 Długosz, lib. 12 (1445-1461), s. 312; ks. 12 (1445-1461), s. 350.

59 G. Rutkowska, Itinerarium..., s. 169; B. Czwojdrak, Zofia..., s. 71, przyp. 91. 
ono 27 grudnia 1459 r., czyli musiało zostać spłodzone pomiędzy początkiem a połową kwietnia $1459 \mathrm{r}$. Od poprzedniego połogu do zajścia w kolejną ciążę Elżbiety minęło zatem około 7 miesięcy. Niewykluczone, że do poczęcia doszło w Wilnie, gdzie z pewnościa król przebywał 2 kwietnia, a królowa mu towarzyszyła. 21 kwietnia 1459 r. Kazimierz Jagiellończyk był w Trokach, następnie w Radomiu i Piotrkowie. Królowa razem z małżonkiem prawdopodobnie wróciła do Krony ${ }^{60}$.

Kazimierz Jagiellończyk kontynuował objazd Korony bez Elżbiety, można jednak przypuszczać, że powiadomiony o stanie królowej 25 grudnia 1459 r. zjawił się Krakowie ${ }^{61}$, gdzie dwa dni później (27 grudnia po godzinie dwunastej) Elżbieta urodziła kolejnego syna, Jana Olbrachta. Tym razem został ochrzczony już po trzech dniach od narodzin, 30 grudnia (w niedzielę), w katedrze krakowskiej przez tytularnego biskupa laodycejskiego, sufragana krakowskiego (franciszkanina) Jerzego ${ }^{62}$. Imię Jan wiązało się z patronem dnia urodzin królewicza, Olbracht - Albrecht było zaś upamiętnieniem jego dziadka macierzystego ${ }^{63}$. Pozostaje oczywiście pytanie, dlaczego to dziecko zostało tak szybko ochrzczone, już trzy dni po urodzeniu. Wprawdzie kilkanaście dni później, 12 stycznia, przybyło do Krakowa poselstwo z Austrii ${ }^{64}$ - z potencjalnymi kandydatami na chrzestnych - ale o tak szybkich chrzcinach Jana Olbrachta widocznie zadecydowały inne względy. Najprostszym domysłem jest stan zdrowia niemowlęcia.

Po narodzinach Jana Olbrachta nastapiło około 11-12 miesięcy przerwy, zanim królowa po raz kolejny (piąty) zaszła w ciążę. Przez pierwsze trzy miesiące 1460 r. (do 19 marca) para królewska przebywała w Krakowie, w kolejnych miesiącach monarcha podróżował już sam, zajmowały go sprawy wojny z zakonem. Rodzina królewska powiększyła się o kolejnego potomka w początkach sierpnia $1461 \mathrm{r}$., jak zatem łatwo wyliczyć ( $280 \mathrm{dni}+-20 \mathrm{dni}$ ), poczęcie nastąpiło w końcu listopada (280 dni) bądź (260 dni) w początkach

60 T. Rombek, Otoczenie, Aneks Itinerarium, s. 268; G. Rutkowska, Itinerarium..., s. $170-171$.

61 G. Rutkowska, Itinerarium..., s. 172-174.

62 Długosz, lib. 12 (1445-14610), s. 338-339; ks. 12 (1445-1461), s. 381; Z. Wdowiszewski, Genealogia Jagiellonów..., s. 103; F. Papee, Jan Olbracht, wyd. 2, Kraków 1992, s. 8.

63 Z. Wdowiszewski, Genealogia Jagiellonów..., s. 102

64 Długosz, lib. 12 (1445-1461), s. 340; ks. 12 (1445-1461), s. 382. 
grudnia 1460 r. Czyli gdzieś w królewskiej trasie objazdowej musiało nastapić spotkanie Kazimierza i Elżbiety. Z itinerarium wiadomo, że król był w Brześciu od 6 do 31 października, ale to zbyt wcześnie (zbyt daleko do daty 5 sierpnia, więcej niż 300 dni), by tam doszło do poczęcia. Następne znane, potwierdzone źródłowo, miejsce pobytu Kazimierza Jagiellończyka to Konin, gdzie był 29 listopada 1460 r., z kolei od 6 do 19 grudnia był na zjeździe w Piotrkowie, a Boże Narodzenie spędził w Łęczycy. Jeśli tu spotkał się z królową i wówczas doszło do poczęcia, to ta ciąża trwała krócej niż 260 dni - tylko około 240-250 dni ${ }^{65}$.

Król po Bożym Narodzeniu z całym dworem i wojskiem przeniósł się do Brześcia ${ }^{66}$, po spędzeniu tam czasu do zapustów (14-17 lutego 1461 r.) udał się do Radomia, do przebywającej tam królowej Zofii. Wydaje się, że skoro mamy informację, iż król razem $\mathrm{z}$ żoną następnie wyjechał na Litwę, to albo Elżbieta też była z Zofią w Radomiu, albo towarzyszyła mężowi w objeździe już od Konina (29 listopada). Na Litwie małżonkowie pozostali aż do późnej wiosny ${ }^{67}$, do Krakowa dotarli 1 czerwca. Od końca czerwca do jesieni król przebywał poza Krakowem, spędzając czas w obozach wojskowych i zajmujac się sprawami wojny ${ }^{68}$.

W tym czasie Elżbieta pozostawała w Krakowie, gdzie doszło do dramatycznych wydarzeń. 16 lipca 1461 r. tłum wtargną do zakrystii kościoła franciszkanów, gdzie schronił się możny małopolski Andrzej Tęczyński, który niezadowolony z ceny za naprawę zbroi wcześniej pobił płatnerza Klemensa. Andrzej został zabity przez mieszczan, a jego towarzysze Spytek z Melsztyna i Mikołaj Sancygniowski bronili się w wieży kościoła, otrzymując gwarancję bezpieczeństwa dopiero rano. Syn zamordowanego, Jan z Rabsztyna, schronił się na Wawelu i dopiero po czterech dniach mieszczanie wydali mu zwłoki ojca ${ }^{69}$. Na królowa, będącą w zaawansowanej ciąży, spadł

65 Długosz, lib. 12 (1445-1461), s. 351; ks. 12 (1445-1461), s. 395; por. G. Rutkowska, Itinerarium..., s. 179; por. jednak T. Rombek, Otoczenie, Aneks Itinerarium, s. 268, wedle którego w czasie Bożego Narodzenia królowej z królem raczej nie było.

66 Długosz, lib. 12 (1445-1461), s. 351; ks. 12 (1445-1461), s. 395; G. Rutkowska, Itinerarium ..., s. 179-180.

67 Długosz, lib. 12 (1445-1461) s. 353; ks. 12 (1445-1461), s. 398; G. Rutkowska, Itinerarium..., s. 180.

68 G. Rutkowska, Itinerarium..., s. 180-182.

69 Szeroko o tym z odniesieniem do źródeł i literatury przedmiotu J. Kurtyka, Tęczyńscy. Studium z dziejów polskiej elity możnowładczej w średniowieczu, Kraków 1997, s. 373-376. 
obowiąek przesłuchania stron konfliktu i powstrzymania rodziny Tęczyńskich przed chęcią odwetu na mieszkańcach Krakowa ${ }^{70}$.

W jakiś czas po tych wydarzenia, 5 sierpnia 1461 r., królowa Elżbieta urodziła piąte dziecko, a czwartego syna, który otrzymał imię Aleksander (po dziadku stryjecznym Witoldzie Aleksandrze). Skoro - jak wszystko na to wskazuje - ciąża ta była najpewniej krótsza niż 260 dni, to można podejrzewać, że wpłynęły na to właśnie wydarzenia z połowy lipca. Nowo narodzony Aleksander został szybko ochrzczony w katedrze krakowskiej przez archidiakona i administratora diecezji krakowskiej Jana Pniowskiego. Jak zaznaczył Jan Długosz, chrzciny były skromne z powodu nieobecności króla i nieszczęścia, jakim było zabójstwo Andrzeja Tęczyńskiego ${ }^{71}$. Jak widać, nie czekano z chrzcinami na króla zajętego sprawami wojennymi ${ }^{72}$. W każdym razie w sierpniu do Krakowa przyjechała królowa Zofia, która niedługo po chrzcinach wnuka zachorowała i zmarła 21 września 1461 r. na zamku na Wawelu. Kazimierz Jagiellończyk miał się dowiedzieć o śmierci matki w Bydgoszczy, czyli pomiędzy 25 a 29 września ${ }^{73}$. Dopiero kilka tygodni później, w grudniu 1461 r., doszło do spotkania królewskich małżonków w Nowym Korczynie, gdy Kazimierze Jagiellończyk dokonał zapisu posagu i wiana dla Elżbiety ${ }^{74}$.

Kolejne dziecko Kazimierza Jagiellończyka urodziło się dopiero w maju 1464 r., zostało więc poczęte około września 1463 r. Widzimy zatem, że nastapiła zmiana dotychczasowych reguł: do tej pory przerwa od urodzin dziecka do kolejnej ciąży trwała maksymalnie rok, teraz dwa lata. Oczywiście można jako wyjaśnienie przyjać częstą nieobecność króla, ta jednak miała miejsce i w poprzednich wypadkach i nie wpływała na tak długa przerwę w powoływaniu na świat kolejnych potomków. Biorąc zatem pod uwagę wcześniejsza kilkuletnią swoista praktykę pary królewskiej, może zastanawiać długi tym razem okres - około 24 miesięcy - bez ponownej ciąży.

Warto więc prześledzić, czy i kiedy Kazimierz Jagiellończyk i Elżbieta od zimy 1461 r. mieli okazję być razem. Przebywali ze sobą

$70 \quad$ Ibidem, s. 377.

71 Długosz, lib. 12 (1445-1461), s. 359; ks. 12 (1445-1461), s. 404; F. Papee, Aleksander Jagiellończyk, wyd. 2, Kraków 1999, s. 9; Z. Wdowiszewski, Genealogia Jagiellonów..., s. 105.

72 G. Rutkowska, Itinerarium..., s. 182.

73 B. Czwojdrak, Zofia..., s. 73.

74 G. Rutkowska, Itinerarium..., s. 184. 
dowodnie od 20 grudnia 1461 aż do lata 1462 r. ${ }^{75}$ Latem i jesienią 1462 królowa była w Nieszawie ${ }^{76}$, król od 4 lipca do 22 sierpnia 1462 r. przebywał w Toruniu, na kilka dni zjawił się w Nieszawie, następnie 31 sierpnia był w Brześciu Kujawskim. Kolejne tygodnie jesieni spędził w Toruniu, Brześciu Kujawskim, Przedeczu, Kłodawie i Łęczycy, zapewne towarzyszyła mu królowa ${ }^{77}$. Następnie wspólnie przebywali w Piotrkowie, skąd w początkach grudnia król udał się w dalszą podróż, ale na Boże Narodzenie zawitał do Radomia, spotykajac się tu z królową ${ }^{78}$. Można zatem stwierdzić, że para królewska - zwłaszcza w drugiej połowie 1462 r. - jeśli się rozstawała, to jedynie na kilka tygodni. W początkach 1463 r. król udał się do Piotrkowa, następnie powrócił do Radomia, skąd wspólnie z żoną na dłuższy czas wyjechał na Litwę. Tam pozostali przez cały Wielki Post, aż do wiosny ${ }^{79}$. Kolejne miesiące spędzili w Polsce, wspólnie byli w Krakowie, a 29 sierpnia i od 2 września do 10 października w Brześciu Kujawskim ${ }^{80}$. Skoro kolejny potomek pary królewskiej urodził się w początkach maja 1464 r., to poczęcie musiało nastapić we wrześniu 1463 r., czyli właśnie w Brześciu Kujawskim. Tym razem królowa była w kolejnej ciąży po 24 miesiącach od ostatniego porodu (5 sierpnia 1461 r.).

Boże Narodzenie 1463 r. król i królowa spędzili w Grodnie ${ }^{81}$. Do Krakowa powrócili 20 kwietnia 1464 r. 28 kwietnia Kazimierz Jagiellończyk wyjechał z Krakowa i do 5 maja przebywał w Nowym Mieście Korczynie ${ }^{82} .6$ maja 1464 r. zjawił się w Krakowie, widocznie powiadomiony, że królowa rodzi. W każdym razie o pierwszej w nocy 6 maja Elżbieta urodziła córkę, którą według Jana Długosza w niedzielę 14 czerwca ochrzcił w katedrze krakowskiej biskup

75 Długosz, lib. 12 (1462-1480), s. 26; ks. 12 (1462-1480), s. 27; T. Rombek, Otoczenie, Aneks Itinerarium, s. 269-2670; G. Rutkowska, Itinerarium..., s. 184-185.

76 Długosz, lib. 12 (1462-1480), s. 40; ks. 12 (1462-1480), s. 44; T. Rombek Otoczenie, Aneks Itinerarium, s. 270.

77 Długosz, lib. 12 (1462-1480), s. 47; ks. 12 (1462-1480), s. 52; T. Rombek, Otoczenie, Aneks Itinerarium, s. 270; G. Rutkowska, Itinerarium ..., s. 189.

78 T. Rombek, Otoczenie, Aneks Itinerarium, s. 270; G, Rutkowska, Itinerarium..., s. 191.

79 Długosz, lib. 12 (1462-1480), s. 57; ks. 12 (1462-1480), s. 63; G. Rutkowska, Itinerarium..., s. 193-194.

80 G. Rutkowska, Itinerarium..., s. 195.

81 Długosz, lib. 12 (1462-1480), s. 79; ks. 12 (1462-1480), s. 86; G. Rutkowska, Itinerarium..., s. 196.

82 G. Rutkowska, Itinerarium..., s. 197. 
krakowski Jan Gruszczyński, nadając jej imię Zofia, nawiązujące do imienia matki króla. Jak już ustalono, chrzciny miały jednak miejsce 13 maja, czyli siedem dni po urodzinach, chrzestnymi byli też dwaj mieszczanie, gdański Johann Meideburg i toruński Conrad Theudenkus, posłowie z Prus do króla w sprawach wojennych $^{83}$. Tylko po narodzinach tego dziecka Jan Długosz napisał, iż na cześć nowo narodzonej królewskiej córki odbyły się igrzyska, a zwycięscy otrzymali nagrody ${ }^{84}$. Nie możemy nie zadać pytania o przyczyny niezwykłej jak na tę pare przerwy w powołaniu na świat kolejnego potomka i - mimo wszystko - dość nadzwyczajnego świętowania narodzin córki, a nie syna. Wydaje się, że o tej przerwie zadecydowała biologia, organizm Elżbiety był zapewne dość wyczerpany poprzednimi częstymi ciążami. Od połowy $1456 \mathrm{r}$. do sierpnia 1461 r., czyli w ciagu 6 lat, królowa była pięciokrotnie w ciąży. Nic zatem dziwnego, że wydanie na świat kolejnego zdrowego potomka, tym razem dziewczynki, przyjęto z taką radością. Ważna dla losów dynastii płodność królowej nie była zagrożona. W październiku/listopadzie 1464 r., czyli już około 4-5 miesięcy po narodzinach Zofii, królowa Elżbieta była ponownie w ciąży. Wiadomo, że 20 czerwca król, zapewne w towarzystwie żony, opuścił Kraków, a od 3 lipca do 17 września 1464 r. pozostawał w Brześciu Kujawskim. W związku z tym, że w okolicach wybuchła zaraza,

83 Długosz, lib. 12 (1462-1480), s. 82; ks. 12 (1462-1480), s. 90; Z. Wdowiszewski, Genealogia Jagiellonów..., s. 110; por. Rozbiór krytyczny..., s. 173, gdzie zwrócono uwagę, że 14 czerwca 1464 r. był czwartek nie niedziela, chrzest odbył się więc albo 10 czerwca, albo 17 czerwca; zob. jednak M. Biskup, Stosunek Gdańska do Kazimierza Jagiellończyka w okresie wojny trzynastoletniej 1454-1466, Toruń 1952 , s. 165 , przyp. 170 - zauważył, że 14 czerwca był czwartek nie niedziela, ale wedle przytoczonej tutaj relacji obecnego wówczas przy królu gdańszczanina Johanna Meideburga chrzciny królewny miały być „jutro”, czyli 13 maja, por. Hanserecesse, 2. Abt., Bd. 5, hrsg. v. G. v. Ropp, Leipzig 1888, nr 466: „dass morgen die junge Tochter des Kg getauft werden soll”. Dodajmy, że 13 maja 1464 r. przypadała niedziela, zob. B. Włodarski, Chronologia polska, Warszawa 2007, s. 368. Na pomyłkę Jana Długosza wskazała też, z pominięciem jednak monografii M. Biskupa, J. Skierska, Terminy koronacji, ślubów, chrztów i pogrzebów polskich władców w średniowieczu [w:] Fontes et historia. Prace dedykowane A. Gasiorowskiemu, red. T. Jurek, J. Skierska, Poznań 2007, s. 211, że chrzest Zofii musiał być w niedzielę. Badaczka ta nie podała jednak, że chrzest miał miejsce 13 maja; zob. też T. Rombek, Otoczenie. Aneks Itinerarium, s. 271 (zgłoszone wątpliwości co do daty chrztu).

84 Długosz, lib. 12 (1462-1480), s. 82; ks. 12 (1462-1480), s. 90; I. Skierska, Terminy koronacji, ślubów, chrztów i pogrzebów polskich władców..., s. 222, tłumaczyła, że intensywność uroczystości na cześć narodzin córek zależała od tego, czy król Kazimierz Jagiellończyk był na miejscu, czy nie. 
Kazimierz Jagiellończyk z Elżbietą pojechali do Kłodawy, gdzie - jak pisał Jan Długosz - przebywali kilka tygodni. Król z Kłodawy udał się na zjazd do Piotrkowa (od 15 do 26 października), a od 11 do 25 listopada był w Parczewie ${ }^{85}$. Jak z tego zatem wynika, do kolejnego poczęcia musiało dojść gdzieś w drodze, pomiędzy wymienionymi miejscowościami. Wiadomo także, iż król w towarzystwie żony spędził święta Bożego Narodzenia na Litwie, w Grodnie. Z powodu zarazy na Litwie przebywano tu do 8 stycznia $1465 \mathrm{r} .{ }^{86}$ Problem z wyznaczeniem nieco dokładniej daty poczęcia, choć oczywiście dalej hipotetycznie, polega na braku pewności co do daty urodzin kolejnego dziecka królewskiej pary. Według Jana Długosza, w wypadku tego dziecka jest to jedyne źródło mówiące o tym wydarzeniu, córka Elżbieta urodziła się w niedzielę, która przypadała w uroczystość Trójcy Świętej, 9 maja, w czasie sumy ${ }^{87}$. Jak objaśnili wydawcy Długoszowych Roczników, kronikarz pomylił datę, uroczystość Trójcy Świętej przypadała bowiem 9 czerwca 1465 r., a 9 maja był w czwartek ${ }^{88}$. Dziewczynka miała zostać ochrzczona w niedzielę 16 maja, jak jednak zauważyli wspominani wydawcy, 16 maja wypadał w tym roku w czwartek, a niedziela 16 czerwca (w polskim wydaniu błędny rok 1466, kiedy niedziela była 15 czerwca) ${ }^{89}$. Trzeba przyznać rację tym badaczom, wedle których Długosz, podając informację o dacie urodzin Elżbiety, pomylił się o miesiąc: „św. Trójcy przypadało w tym roku na dzień 9 czerwca, nie zaś maja, a niedziela po św. Trójcy przypadała na 16 czerwca" ${ }^{90}$. Wydaje się zatem, że Elżbieta, która otrzymała

85 Długosz, lib. 12 (1462-1480), s. 83, 92, 96-97; ks. 12 (1462-1480), s. 90, 103, 106-107; G. Rutkowska, Itinerarium..., s. 199-200-201; T. Rombek, Otoczenie. Aneks itinerarium, s. 271.

86 Długosz, lib. 12 91462-1480), s. 100; ks. 12 (1462-1480), s. 110; G. Rutkowska, Itinerarium ..., s. 201.

87 Długosz, lib. 12 (1462-1480), s. 110; ks. 12 (1462-1480), s. 120, gdzie błędne tłumaczenie daty jako „przed” a nie „w”. Zwróciła na to uwagę I. Skierska, Terminy koronacji, ślubów, chrztów i pogrzebów polskich władców..., s. 221, przyp. 59.

88 Długosz, lib. 12 (1462-1480), s. 110, przyp. 55; ks. 12 (1462-1480), s. 120, przyp. 48; zob. też B. Włodarski, Chronologia polska..., s. 394-395 (Wielkanoc, 14 kwietnia); Z. Wdowiszewski, Genealogia Jagiellonów..., s. 114. Odnośnie do tego ostatniego badacza uwaga I. Skierskiej, Terminy koronacji, ślubów, chrztów i pogrzebów polskich władców..., s. 221, przyp. 59, że nie dokonał sprawdzenia dat podawanych przez Długosza.

89 W łacińskim wydaniu Długosz, lib. 12 (1462-1480), s. 110, przyp. 56 prawidłowo podany rok 1465; ks. 12 (1462-1480), s. 120, przyp. 49; B. Włodarski, Chronologia polska..., s. 395.

90 Rozbiór krytyczny..., s. 184; zob. też. I. Skierska, Terminy koronacji, ślubów, chrztów i pogrzebów..., s. 221 oraz G. Rutkowska, Itinerarium..., s. 204. 
imię na cześć babki macierzystej, przyszła na świat w Krakowie nie 9 maja, ale o miesiąc później, 9 czerwca. Takie ustalenie znajduje też pośrednie potwierdzenie w itinerarium króla, który jeszcze od 6 do 9 maja był we Lwowie, następnie szybkimi podwodami zjawił się na majowym zjeździe w Nowym Korczynie, a 29 maja przybył do Krakowa, w którym pozostawał aż do 5 lipca ${ }^{91}$. Jeśli chrzest miał miejsce 16 czerwca (nie 16 maja, jak pisał pomyłkowo Jan Długosz), to król był obecny na tej uroczystości. Wiadomo, że ceremonii chrztu dokonali biskup krakowski Jan Lutkowic z Brzezia, włocławski Jakub z Sienna, w obecności książąt: cieszyńskiego Przemysława, raciborskiego Janusza, toszeckiego Przemka, zatorskiego Wacława, gliwickiego Janusza i rybnickiego Jana ${ }^{92}$.

Pod rokiem 1466 Jan Długosz zanotował, że 16 maja na zamku w Nowym Mieście Korczynie zmarła osłabiona wieloma chorobami córka królewska Elżbieta, przewieziona do Krakowa została pochowana w grobowcu królowej Anny Cylejskiej ${ }^{93}$. Pozostaje pytanie, czy królowa Elżbieta była przy śmierci córeczki - wiadomo, że wraz z mężem do 26 kwietnia przebywała w Łęczycy. Tomasz Rombek sugeruje, że Elżbieta nie towarzyszyła Kazimierzowi Jagiellończykowi w podróży do Brześcia Kujawskiego (pobyt króla w tym mieście jest poświadczony 25 maja), tylko przez kolejne miesiące pozostawała w Łęczycy. Badacz ten nie wyklucza jednak, że kiedy król był w Toruniu (od 7 września do 28 października), prowadząc rokowania pokojowe z zakonem krzyżackim, królowa przebywała w Nieszawie ${ }^{94}$. Taka luka chronologiczna: kwiecień - wrzesień 1466 r., kiedy nie wiadomo, gdzie czas spędzała Elżbieta, pozwala przyjąć ostrożnie, że była w maju w Nowym Mieście Korczynie, gdzie zmarła jej roczna córeczka.

91 G. Rutkowska, Itinerarium..., s. 203.

92 Długosz, lib. 12 (1462-1480), s. 110-111; ks. 12 (1462-1480), s. 120-121.

93 Długosz, lib. 12 (1462-1480), s. 132; ks. 12 (1468-1480), s. 142; por. jednak Długosz, lib. 12 (1462-1480), s. 110; ks. 12 (1462-1480), s. 120-121, gdzie pod 1465 r., że zmarła w tym samym dniu, co się urodziła, miało to mieć miejsce ('smierć) w Sandomierzu, i że została pochowana w katedrze krakowskiej, w grobowcu swojej babki Jadwigi (takie tłumaczenie w polskim wydaniu). Wydawcy obu wydań wskazują na Jadwigę, córkę Władysława Jagiełły i Anny Cylejskiej, czyli nie babkę, jak w polskim wydaniu, a ciotkę - siostrę przyrodnią Kazimierza Jagiellończyka, zob. Z. Wdowiszewski, Genealogia Jagiellonów..., s. 114-115, dla którego było oczywiste, że Długosz pisał o pochówku w grobie ciotki, Jadwigi. Wyjaśnił też, że określenia grób Jadwigi i grób Anny oznaczają to samo, Jadwiga została bowiem pochowana w grobie swej matki Anny.

94 T. Rombek, Otoczenie, Aneks Itinerarium, s. 273 
W każdym razie przerwa pomiędzy narodzinami Elżbiety (zmarłej w 1466 r.) a kolejną ciążą wyniosła około 10-11 miesięcy. 5 lipca 1465 r. Kazimierz Jagiellończyk opuścił Kraków i udał się w kilkumiesięczny objazd, nie wiadomo jednak, czy towarzyszyła mu Elżbieta. Po 25 listopada król zjawił się w Kozienicach, skąd skierował się na Litwę ${ }^{95}$. W podróży tej towarzyszyła mu Elżbieta, wiadomo bowiem, że Boże Narodzenie 1465 r. małżonkowie spędzili w Wilnie ${ }^{96}$. W marcu para królewska powróciła do Polski ${ }^{97}$, królowa zatrzymała się w Radomiu, król kontynuował zaś objazd po kraju. Małżonkowie spotkali się ponownie 6 kwietnia w Łęczycy, gdzie spędzili przypadajaccą tego dnia Wielkanoc i pozostawali tu do 29 kwietnia ${ }^{98}$. Ponieważ kolejne dziecko przyszło na świat w styczniu 1467 r., do poczęci musiało dojść wiosna, najpewniej w końcu kwietnia 1466 r. Czyli można z dużą dozą prawdopodobieństwa przyjąć, że to właśnie w Łęczycy (między 6 a 29 kwietnia) królowa zaszła w ciązę. 6 kwietnia świętowano Wielkanoc, więc do poczęcia mogło dojść po tej dacie. Z Łęczycy król udał się na Kujawy i do Toruniu ${ }^{99}$. Nie wiadomo, kiedy dokładnie dołączyła doń ciężarna Elżbieta. W każdym razie 8 listopada królewska para, ze względu na szalejąca zarazę, zjawiła się nie w Krakowie, gdzie jak dotąd przychodziły na świat ich dzieci, lecz skierowała się do wiejskiej, może bezpieczniejszej dla zdrowia posiadłości, do Kozienic. Tam spędzili Boże Narodzenie w oczekiwaniu narodzin kolejnego potomka. 1 stycznia 1467 r. koło północy (czyli z 1 na 2 stycznia) królowa Elżbieta urodziła kolejnego syna, było to pierwsze dziecko, które przyszło na świat poza Wawelem. W Kozienicach (bliższa data nie jest znana) ochrzcił go biskup krakowski Jan Lutkowic z Brzezia, chłopiec otrzymał imię po Zygmuncie Luksemburczyku i po wielkim księciu litewskim Zygmuncie ${ }^{100}$. W Kozienicach rodzina królewska spędziła czas do 29 stycznia,

95 G. Rutkowska, Itinerarium..., s. 203-206, por. T. Rombek, Otoczenie, Aneks Itinerarium, s. 272.

96 Długosz, lib. 12 (1462-1480), s. 123; ks. 12 (1468-1480), s. 133; T. Rombek, Otoczenie, Aneks Itinerarium, s. 272; G. Rutkowska, Itinerarium ..., s. 206.

97 Długosz, lib. 12 (1462-1480), s. 128; ks. 12 (1468-1480), s. 138; T. Rombek, Otoczenie, Aneks Itinerarium, s. 272-273; G. Rutkowska, Itinerarium..., s. 206.

98 Długosz, lib. 12 (1462-1480), s. 130; ks. 12 (1462-1480), s. 140; T. Rombek,

Otoczenie, Aneks Itinerarium, s. 273; G Rutkowska, Itinerarium..., s. 208.

99 G Rutkowska, Itinerarium..., s. 208-211.

100 Długosz, lib. 12 (1462-1480), s. 178; ks. 12 (1462-1480), s. 186-187; Z. Wdowiszewski, Genealogia Jagiellonów..., s. 115. 
skąd udała się na Litwę ${ }^{101}$, wiosną 1467 r. ruszyli przez Drohiczyn do Radomia, stąd król odesłał żonę z dziećmi i bagażami do Nowego Korczyna, sam wyruszył do Piotrkowa (pobyt od 3 do 25 maja) ${ }^{102}$.

Około 8 miesięcy po narodzinach Zygmunta królowa była ponownie w ciąży. Kolejne dziecko przyszło na świat 27 kwietnia 1468 r., czyli nietrudno obliczyć, że poczęcie musiało nastąpić w sierpniu/ wrześniu 1467 r. Wiadomo, że para królewska, po kilkutygodniowej rozłące, spotkała się w 1467 r. w Niepołomicach. Król przybył tu po 10 czerwca. Małżonkowie wspólnie ruszyli z Niepołomic do Krakowa. Pobyt króla w Krakowie jest poświadczony w źródłach od 27 czerwca do 1 października 1467 r. ${ }^{103}$ Można więc śmiało stwierdzić, iż kolejny potomek został spłodzony w stołecznym mieście. Po pobycie w Krakowie para królewska skierowała się na Litwę, gdzie przebywała aż do marca $1468^{104}$. Małżonkowie powrócili do Krakowa 13 kwietnia 1468 r. ${ }^{105}$, tam oczekując już narodzin kolejnego potomka.

27 kwietnia 1468 r. królowa Elżbieta na zamku w Krakowie, po godzinie 16.00, urodziła kolejnego syna, który 8 maja został ochrzczony w katedrze krakowskiej przez biskupa krakowskiego Jana Lutkowica z Brzezia. Ojcem chrzestnym był biskup Ołomuńca Protazy, który akurat przybył z poselstwem do Krakowa i na którego prośby (tak Jan Długosz) chłopiec otrzymał imię Fryderyk $^{106}$; można się domyślać, że na cześć Fryderyka III Habsburga.

Po narodzinach Fryderyka ponownie nastapiła dłuższa przerwa w pojawianiu się na świecie potomków Kazimierza i Elżbiety. Wydaje się, że i tym razem przyczyną było zdrowie królowej. Nie możemy też wykluczyć, iż po narodzinach Fryderyka, a przed grudniem 1470 r., królowa była w ciąży, ale poroniła i chorowała. Jan Długosz odnotował bowiem ślub złożony przez króla Kazimierz

101 Długosz, lib. 12 (1462-1480), s. 178; ks. 12 (1462-1480), s. 187; G. Rutkowska, Itinerarium ..., s. 211-212.

102 Długosz, lib. 12 (1462-1480), s. 182, 189; ks. 12 (1462-1480), s. 191, 199;

T. Rombek, Otoczenie, Aneks Itinerarium, s. 273; G. Rutkowska, Itinerarium ..., s. 212.

103 Długosz, lib. 12 (1462-1480), s. 188; ks. 12 (1462-1480), s. 197; T. Rombek, Otoczenie, Aneks Itinerarium,s. 273-274; G. Rutkowska, Itinerarium..., s. 214-216.

104 Długosz, lib. 12 (1462-1480), s. 206-207; ks. 12 (1462-1480), s. 217; G. Rutkowska, Itinerarium..., s. 216-217.

105 Długosz, lib. 12 (1462-1480), s. 207-208; ks. 12 (1462-1480), s. 218; T. Rombek, Otoczenie, Aneks Itinerarium, s. 274; G. Rutkowska, Itinerarium..., s. 217.

106 Długosz, lib. 12 (1462-1480), s. 210-211; ks. 12 (1462-1480), s. 221; Z. Wdowiszewski, Genealogia Jagiellonów..., s. 125. 
Jagiellończyk, iż jeśli królowa wyzdrowieje, to wspólnie odbędą pielgrzymkę do Poznania do tamtejszego klasztoru Bożego Ciała ${ }^{107}$ - faktycznie w początkach grudnia $1470 \mathrm{r}$. królewska para złożyła wizytę w tym klasztorze (zob. poniżej).

W każdym razie, po narodzinach i chrzcinach Fryderyka, małżonkowie pozostali w Krakowie do 27 czerwca 1468 r. ${ }^{108}$ Po tej dacie ruszyli w objazd, 3 sierpnia król udał się do Prus, królowa pojechała zaś do Nieszawy, gdzie spędziła sierpień i wrzesień ${ }^{109}$. Małżonkowie spotkali się w Toruniu z końcem września i skierowali do Piotrkowa, dalej do Opoczna, Skrzynna, Radomia, Jedlina, klasztoru łysogórskiego, a następnie do Nowego Miasta Korczyna. Tu świętowali Boże Narodzenie, po Nowym Roku do 5 stycznia 1469 r. król był w Niepołomicach, gdzie polował ${ }^{110}$. Kiedy król i królowa wjechali do Krakowa (5 stycznia), zostali powitani przez czterech synów: Władysława, Kazimierza, Jana Olbrachta i Aleksandra. Najstarszy i pierworodny Władysław (miał wówczas 13 lat) wygłosił „bardzo piękne przemówienie”111.

29 stycznia 1469 r. Kazimierz Jagiellończyk i Elżbieta opuścili Kraków i udali się na Ruśs ${ }^{112}$. Po spędzonej na tam Wielkanocy powrócili do Krakowa, gdzie przebywali od 27 kwietnia do 19 czerwca $^{113}$. Kolejne miesiące małżonkowie spędzili także razem, przebywając między innymi na Litwie ${ }^{114}$. We września 1469 r. powrócili do Polski, Kazimierz pozostawił żonę (z bagażami, jak pisał

107 Długosz, lib. 12 (1462-1480), s. 260; ks. 12 (1462-1480), s. 272; zob. U. Borkowska, Polskie pielgrzymki Jagiellonów [w:] Peregrinationes. Pielgrzymki w kulturze dawnej Europy, red. H. Manikowska i H. Zaremska, Warszawa 1995, s. 189-190; eadem, Dynastia..., s. 409; też A. Nalewajek, Na królewskim dworze Jana Olbrachta, „Roczniki Humanistyczne” 2011, t. 69, z. 2, s. 77.

108 T. Rombek, Otoczenie, Aneks Itinerarium, s. 274; G. Rutkowska, Itinerarium..., s. 217.

109 T. Rombek, Otoczenie, Aneks Itinerarium, s. 274; G. Rutkowska, Itinerarium..., s. 218-221.

110 Długosz, lib. 12 (1462-1480), s. 226-227; ks. 12 (1462-1480), s. 238-239:

G. Rutkowska, Itinerarium..., s. 221.

111 Długosz, lib. 12 (1462-1480), s. 228; ks. 12 (1462-1480), s. 239; U. Borkowska, Dynastia..., s. 367.

112 Długosz, lib. 12 (1462-1480), s. 228-229; ks. 12 (1462-1480), s. 239; G. Rutkowska, Itinerarium...., s. 221-223.

113 T. Rombek, Otoczenie, Aneks Itinerarium, s. 275; G. Rutkowska, Itinerarium..., s. 223 .

114 T. Rombek, Otoczenie, Aneks Itinerarium, s. 275; G. Rutkowska, Itinerarium..., s. 224-225. 
Długosz) w Radomiu, sam udał się do Piotrkowa. Stamtąd król wrócił do Radomia i z żoną ruszył na Litwę, gdzie para królewska spędziła Boże Narodzenie ${ }^{115}$. Powrót do Polski nastapił w początku kwietnia 1470 r., w kolejnych miesiącach królowa niemal stale towarzyszyła mężowi. Jesienią 1470 r. przybyli do Lublina, skąd Kazimierz Jagiellończyk odesłał żonę ponownie do Radomia ${ }^{116}$. Małżonkowie się spotkali w końcu października w Piotrkowie ${ }^{117}$. Jak już wspomniano, 6 grudnia 1470 r. królowa i król złożyli wizytę w Poznaniu, w tamtejszym klasztorze Bożego Ciała ${ }^{118}$. Boże Narodzenie 1470 r. spędzili w Radomiu, skąd udali się na Litwę ${ }^{119}$, gdzie zostali aż do wiosny (co prawda Długosz pisał tylko o królu, ale małżonkowie byli chyba razem) ${ }^{120}$. Od 12 maja do 25 lipca $1471 \mathrm{r}$. przebywali razem w Krakowie, skąd król udał się na pewien czas na Litwę ${ }^{121} .30$ lipca Kazimierz Jagiellończyk wrócił do Krakowa ${ }^{122}$, gdzie pozostał do 4 października ${ }^{123}$.

Wedle już zaprezentowanych w innymi miejscu ustaleń kolejne dziecko królewskiej pary przyszło na świat 20 kwietnia 1472 r. ${ }^{124}$, zatem od około połowy sierpnia $1471 \mathrm{r}$. królowa była w ciąży i tym razem (jak w wypadku Fryderyka) poczęcie miało miejsce w Krakowie. Król tylko na krótko opuścił to miasto

115 Długosz, lib. 12 (1462-1480), s. 246; ks. 12 (1462-1480), s. 257; G. Rutkowska, Itinerarium ..., s. 226-227.

116 Długosz, lib. 12 (1462-1480), s. 257; ks. 12 (1462-1480), s. 269; T. Rombek, Otoczenie, Aneks Itinerarium, s. 276.

117 T. Rombek, Otoczenie, Aneks Itinerarium, s. 276; G. Rutkowska, Itinerarium..., s. 229.

118 Długosz, lib. 12 (1462-1480), s. 260; ks. 12 (1462-1480), s. 272; T. Rombek, Otoczenie, Aneks Itinerarium, s. 277; G. Rutkowska, Itinerarium..., s. 231.

119 Długosz, lib. 12 (1462-1480), s. 263; ks. 12 (1462-1480), s. 275; G. Rutkowska, Itinerarium..., s. 231.

120 Długosz, lib. 12 (1462-480), s. 263; ks. 12 (1462-1480), s. 275; T. Rombek, Otoczenie, Aneks Itinerarium..., s. 277

121 G. Rutkowska, Itinerarium..., s. 233.

122 Rachunki wielkorzadowe krakowskie z r. 1471, wyd. R. Grodecki, Kraków 1951, nr 89; T. Rombek, Otoczenie, Aneks Itinerarium, s. 277; G. Rutkowska, Itinerarium..., s. 235.

123 G. Rutkowska, Itinerarium..., s. 235, pobyt tam z przerwa: 12-13 sierpnia oraz 21-22 sierpnia, gdy polował w Niepołomicach.

124 Szerzej zob. B. Możejko, Dzienna data urodzin Elżbiety (2), córki Kazimierza Jagiellończyka i Elżbiety Rakuszanki [w:] Miasto i państwo na przestrzeni dziejów. Studium historyczno-prawne. Księga jubileuszowa z okazji czterdziestopięciolecia pracy naukowej oraz 70. urodzin Profesora Tadeusza Maciejowskiego, Gdańsk 2020, s. $323-328$. 
(po 4 do 23 października przebywając w Nowym Saczu ${ }^{125}$ ), następnie do marca $1472 \mathrm{r}$. był w Krakowie, ruszył następnie w krótki objazd, ale wrócił do Krakowa 12 kwietnia, a już 20 tego miesiąca na świat przyszła córka, której na pamiątkę zmarłej wcześniej siostry dano na chrzcie, udzielonym przez biskupa krakowskiego Jana Rzeszowskiego 26 kwietnia, imię Elżbieta ${ }^{126}$.

Po narodzinach dziewczynki nastapiła ponownie dłuższa, tym razem ponadtrzyletnia przerwa, zanim królowa była ponownie w ciąży. Elżbieta w 1472 r. miała około 36-37 lat i urodziła w latach 1456-1472 już dziesięcioro dzieci, czyli prawie połowę z tych 16 lat (192 miesiące) zajęły jej kolejne ciąże (90 miesięcy).

Para królewska spędziła w Krakowie kolejne miesiące, 20 sierpnia 1472 r., czyli gdy mała Elżbieta miała 4 miesiące, z powodu panującej zarazy małżonkowie wraz ze wszystkimi dziećmi wyjechali do Niepołomic ${ }^{127}$. Stąd skierowano się do Nowego Korczyna, po 8 tygodniach, przed 1 listopada, król odesłał żonę (z dziećmi?) do klasztoru w Sulejowie, sam zaś udał się na zjazd do Piotrkowa ${ }^{128}$. Był tam od 1 do 18 listopada, następnie przebywał w Tuszynie i Łęczycy, skąd ruszył do Poznania, ponownie do klasztoru Bożego Ciała, „aby spełnić swe pobożne złożone Bogu śluby”129. Nie wiemy, czy towarzyszyła mu królowa. W każdym razie wydaje się, iż król złożył śluby podczas pierwszej wizyty w tym klasztorze i dotyczyły one zdrowia królowej, a tym razem stanowiły podziękowania króla za szczęśliwe rozwiązanie ${ }^{130}$.

Od 1472 r., jak już wspominano, przerwa w powoływaniu potomka trwała aż ponad trzy lata, kolejne dziecko urodziło się w marcu 1476 r. Pozostaje zatem pytanie, na ile wpływ na tę przerwę miało

125 G. Rutkowska, Itinerarium..., s. 236-237.

126 Długosz, lib. 12 (1462-1480), s. 288; ks. 12 (1462-1480), s. 302. Jan Długosz nie podał jednak w Rocznikach daty chrztu, zob. U. Borkowska, Królewskie zaślubiny..., s. 81, przyp. 62 (ale bez żadnego komentarza); por. I. Skierska, Terminy koronacji, ślubów, chrztów i pogrzebów..., s. 222, przyp. 60 i B. Możejko, Dzienna data urodzin Elżbiety (2)..., s. 323-328.

127 Długosz, lib. 12 (1462-1480), s. 293; ks. 12 (1462-1480), s. 307.

128 Długosz, lib. 12 (1462-1480), s. 294-295; ks. 12 (1462-1480), s. 308-309; T. Rombek, Otoczenie, Aneks Itinerarium, s. 278; G. Rutkowska, Itinerarium..., s. $242-243$.

129 Długosz, lib. 12 (1462-1480), s. 296-297; ks. 12 (1462-1480), s. 311; G. Rutkowska, Itinerarium..., s. 244.

130 Wedle U. Borkowskiej, Dynastia..., s. 409, motywy tej drugiej pielgrzymki mogły być tė̇ polityczne. 
zdrowie królowej, na ile zaś na przykład liczne podróże króla bez małżonki. Pozostawiając problemy zdrowotne jako kwestię otwarta, poświęćmy więcej uwagi monarszemu itinerarium oraz miejscom pobytu królowej. Późna jesienią Kazimierz Jagiellończyk z Poznania, przez Koło udał się do Torunia, gdzie miał miejsce zjazd ze stanami Prus Królewskich (6-30 grudnia 1472 r.). Przybyła tu również królowa; małżonkowie spędzili w Toruniu Boże Narodzenie ${ }^{131}$. Z Torunia przez Brześć Kujawski, Sochaczew i Warszawę udali się na Litwę, gdzie pozostawali do kwietnia 1473 r. Tomasz Rombek wyraził ostrożne przypuszczenie, że królowa towarzyszyła mężowi w drodze do Krakowa (przez: Piotrków - Radom - klasztor łysogórski - Nowe Miasto Korczyn) w okresie od maja do sierpnia 1473 r. ${ }^{132}$ Wiadomo, że Boże Narodzenie 1473 r. i kolejne tygodnie do 31 stycznia 1474 r. spędził Kazimierz Jagiellończyk z małżonką w Wiślicy ${ }^{133}$. Można zatem stwierdzić, że w 1473 r. para sporo czasu przebywała razem. Identyczną uwagę można zgłosić do roku 1474. Dopiero jesienią 1474 r. król wyjechał na dłużej sam, kierując się na Śląsk i biorąc udział w wyprawie czeskiej ${ }^{134}$. W grudniu 1474 r. był już jednak w Łęczycy, gdzie prowadził negocjacje w sprawie małżeństwa swej najstarszej córki Jadwigi z księciem bawarskim Jerzym Bogatym z Wittelsbachów ${ }^{135}$. Boże Narodzenie 1474 r. Kazimierz Jagiellończyk spędził w Łęczycy w towarzystwie małżonki ${ }^{136}$.

Po Bożym Narodzeniu 1474 r. para królewska udała się na Litwę, gdzie spędziła Wielkanoc 1475 r. ${ }^{137}$ Jak już wspomniano, kolejny potomek przyszedł na świat 12 marca $1476 \mathrm{r}$., królowa musiała zajść w ciążę zatem w czerwcu $1475 \mathrm{r}$. Wiadomo, że małżonkowie od 5 do 20 czerwca 1475 r. przebywali w Lublinie,

131 Długosz, lib. 12 (1462-1480), s. 299-300; ks. 12 (1462-1480), s. 314; T. Rombek, Otoczenie, Aneks Itinerarium, s. 278; G. Rutkowska, Itinerarium..., s. 244-245.

132 Długosz, lib. 12 (1462-1480), s. 306-308; ks. 12 (1462-1480), s. 321-323;

T. Rombek, Otoczenie, Aneks Itinerarium, s. 279.

133 Długosz, lib. 12 (1462-1480), s. 322-323; ks. 12 (1462-1480), s. 337; T. Rombek, Otoczenie, Aneks Itinerarium, s. 279.

134 Długosz, lib. 12 (1462-1480), s. 345-346; ks. 12 (1462-1480), s. 356; G. Rutkowska, Itinerarium..., s. 257-260.

135 Długosz, lib. 12 (1462-1480), s. 348; ks. 12 (1462-1480), s. 364; G. Rutkowska, Itinerarium ..., s. 261.

136 Długosz, lib. 12 (1462-1480), s. 350; ks. 12 (1462-1480), s. 366; T. Rombek, Otoczenie, Aneks Itinerarium, s. 280; G. Rutkowska, Itinerarium..., s. 261.

137 Długosz, lib. 12 (1462-1480), s. 351; ks. 12 (1462-1480), s. 367; G. Rutkowska, Itinerarium ..., s. 262, do 14 kwietnia. 
następnie 22 czerwca w Zawichoście, po 22 czerwca w Sandomierzu, a od 29 czerwca do 4 sierpnia w Nowym Korczynie ${ }^{138}$. W którymś z tych miejsc zostało więc poczęte jedenaste dziecko. Po pobycie w Nowym Korczynie król udał się w objazd, nie wiadomo, czy królowa mu towarzyszyła. Razem byli następnie w Krakowie, skąd wyjechali wspólnie z córką Jadwiga, która kierowała się do Bawarii, by spotkać tam swego narzeczonego księcia Jerzego. Pożegnanie rodziców z córką miało miejsce 10 października 1475 r. w Poznaniu ${ }^{139}$. Elżbieta była już wówczas w ciąży, prawdopodobnie w czwartym miesiącu. Wiadomo, że małżonkowie spędzili Boże Narodzenie w Kole, na kolejny dłuższy pobyt zatrzymali się w Brześciu Kujawskim, gdzie król przebywał do 9 kwietnia, a królowa 10 marca udała się do Nieszawy ${ }^{140}$, rodząc tam 12 marca 1476 r. córkę. Dziewczynka otrzymała na chrzcie, udzielonym przez biskupa chełmińskiego Wincentego Kiełbasę, imię Anna ${ }^{141}$, upamiętniając zapewne Annę Cylejską (drugą żonę Władysława Jagiełły). Król dołączył do małżonki i już kilkutygodniowej córki dopiero po 9 kwietnia ${ }^{142}$.

Po urodzeniu tego dziecka nastapiła okołopółtoraroczna przerwa, zanim królowa ponownie zaszła ciążę. Wiadomo, że Elżbieta aż do sierpnia 1476 r. pozostała w Nieszawie, tymczasem król udał się już w kwietniu do Prus, między innymi na zjazd do Malborka (tu przebywał do 3 sierpnia) ${ }^{143}$. Małżonkowie po tym kilkumiesięcznym rozstaniu spotkali się zapewne w sierpniu/wrześniu w Piotrkowie ${ }^{144}$. Stamtąd razem udali się do Radomia, gdzie Elżbieta jakiś czas pozostała, a Kazimierz wyjechał do klasztoru łysogórskiego, następnie do Nowego Korczyna i Sandomierza. Dnia 28 września dotarł do Lublina, gdzie już czekała na niego królowa, przybyła wcześniej

138 T. Rombek, Otoczenie, Aneks Itinerarium, s. 281; G. Rutkowska, Itinerarium..., s. 263.

139 T. Rombek, Otoczenie, Aneks Itinerarium, s. 281; G. Rutkowska, Itinerarium..., s. 264-265.

140 T. Rombek, Otoczenie, Aneks Itinerarium, s. 281; G. Rutkowska, Itinerarium..., s. 266-269.

141 Długosz, lib. 12 (1462-1480), s. 373; ks. 12 (1462-1480), s. 389; Z. Wdowiszewski, Genealogia Jagiellonów..., s. 129-130.

142 G. Rutkowska, Itinerarium..., s. 269.

143 T. Rombek, Otoczenie, Aneks Itinerarium, s. 281; G. Rutkowska, Itinerarium..., s. 269-272.

144 T. Rombek, Otoczenie, Aneks Itinerarium, s. 281; G. Rutkowska, Itinerarium..., s. 272- 273 . 
z Radomia ${ }^{145}$. Z Lublina małżonkowie skierowali się na Litwę, gdzie świętowali Boże Narodzenie 1476 r. i spędzili razem czas aż do marca 1477 r. ${ }^{146}$ Od 2 do 9 kwietnia 1477 r. byli w Lublinie, skąd Elżbieta pojechała do Radomia, a król na zjazd do Piotrkowa ${ }^{147}$. Kolejnym miejscem ich wspólnego pobytu od 14 maja do 8 lipca 1477 r. był Nowy Korczyn ${ }^{148}$. Ponieważ następne dziecko urodziło się w połowie lipca 1478 r., to można założyć, iż do jego poczęcia doszło w listopadzie 1477 r., czyli półtora roku od poprzedniego rozwiązania. Stało się to w Krakowie, tam bowiem para królewska przebywała od lipca (7-9) niemal do końca listopada 1477 r. ${ }^{149}$

Boże Narodzenie 1477 r. małżonkowie spędzili w Radomiu ${ }^{150}$, po czym król, zostawiwszy tam królową wraz z całym dworem, udał się do Piotrkowa, zabierając ze sobą syna Kazimierza ${ }^{151}$. Po prawie miesięcznym pobycie w Piotrkowie król pojechał do Łęczycy, gdzie musiała być też królowa, skoro tłumaczyła wypowiedzi tajnego posła przybyłego od panów węgierskich (czyli chyba mówił po niemiecku i tłumaczyła tylko królowa Elżbieta) ${ }^{152}$. Następnie król Kazimierz Jagiellończyk odesłał żonę do Radomia (była w czwartym miesiącu ciąży), sam udał się do Brześcia Kujawskiego ${ }^{153}$, a stamtąd - w towarzystwie Kazimierza i Jana Olbrachta - do Brześcia Litewskiego ${ }^{154}$.

145 Długosz, lib. 12 (1462-1480), s. 385; ks. 12 (1462-1480), s. 400; T. Rombek, Otoczenie, Aneks Itinerarium, s. 281; G. Rutkowska, Itinerarium..., s. 273-274.

146 Długosz, lib. 12 (1462-1480), s. 390; ks. 12 (1462-1480), s. 406-407 (Długosz wspomniał o obecności na Litwie z rodzicami obu synów Kazimierza i Jana Olbrachta); T. Rombek, Otoczenie, Aneks Itinerarium, s. 282; G. Rutkowska, Itinerarium..., s. 274-275.

147 Długosz, lib. 12 (1462-1480), s. 391; ks. 12 (1462-1480), s. 406-407; T. Rombek, Otoczenie, Aneks Itinerarium, s. 282; G. Rutkowska, Itinerarium ..., s. 275-276.

148 T. Rombek, Otoczenie, Aneks Itinerarium, s. 282, słusznie podkreśla, że nie wiadomo, kiedy królowa przyłączyła się do króla w jego podróży do Nowego Korczyna; G. Rutkowska, Itinerarium ..., s. 276-277.

149 T. Rombek, Otoczenie, Aneks Itinerarium, s. 283; G. Rutkowska, Itinera$\operatorname{rium} \ldots$, s. 277.

150 Długosz, lib. 12 (1462-1480), s. 405-406; ks. 12 (1462-1480), s. 421; T. Rombek, Otoczenie, Aneks Itinerarium, s. 283; G. Rutkowski, Itinerarium..., s. 280. 151 Długosz, lib. 12 (1462-1480), s. 406-407; ks. 12 (462-1480), s. 422; por. G. Rutkowska, Itinerarium..., s. 280, pobyt tam od 12 stycznia do 6 lutego 1478 r.

152 Długosz, lib. 12 (1462-1480), s. 408; ks. 12 (1462-1480), s. 423; T. Rombek, Otoczenie, Aneks Itinerarium, s. 284.

153 Długosz, lib. 12 (1462-1480), s. 408; ks. 12 (1462-1480), s. 423; T. Rombek, Otoczenie, Aneks Itinerarium, s. 284; G. Rutkowska, Itinerarium..., s. 281.

154 Długosz, lib. 12 (1462-1480), s. 409; ks. 12 (1462-1480), s. 424-425; G. Rutkowska, Itinerarium..., s. 281. 
Małżonkowie spotkali się przed kolejnym rozwiąaniem. Kazimierz Jagiellończyk z Piotrkowa przyjechał do Radomia, gdzie czekała na niego Elżbieta i razem ruszyli do Sandomierza. Król ze starszymi synami przybył tu przed małżonka, której orszak, zapewne obarczony młodszymi dziećmi, podróżował wolniej ${ }^{155}$. 15 lipca 1478 r. w Sandomierzu przyszła na świat kolejna królewska córka, Barbara. Nadane jej imię miało zapewne upamiętniać Barbarę Cylejska, babkę królowej Elżbiety. Dziewczynka została ochrzczona w niedzielę 26 lipca w kościele NMP w Sandomierzu przez biskupa krakowskiego Jana Rzeszowskiego ${ }^{156}$.

Barbara była ostatnim dzieckiem królewskiej pary urodzonym za życia Jana Długosza, notującego na potrzeby swojej kroniki daty ich przyjścia na świat. Po śmierci kronikarza, 19 maja 1480 r., miało miejsce jeszcze kilka faktów genealogicznych dotyczących królewskiej rodziny ${ }^{157}$, nie do wszystkich jesteśmy jednak pewni dat. Wiadomo, że wkrótce po $1480 \mathrm{r}$. zmarła w wieku około 8 lat córka królewska Elżbieta (2) ${ }^{158}$, około 1483 r. urodziło się zaś ostatnie dziecko Kazimierza Jagiellończyka i Elżbiety. Dziewczynce nadano imię Elżbieta, po zmarłej siostrze ${ }^{159}$. Żadne źródło nie notuje daty śmieci Elżbiety (2) ani daty rocznej narodzin Elżbiety (3). Wiadomo tylko, że ostatnia córka urodziła się 13 listopada ${ }^{160}$. Przybliżoną datę roczną urodzin tej Elżbiety na 1483 r. wyznaczono w historiografii na podstawie adnotacji Rocznika świętokrzyskiego

155 Długosz, lib. 12 (1462-1480), s. 416; ks. 12 (1462-1480), s. 431; T. Rombek, Otoczenie, Aneks Itinerarium, s. 284; G. Rutkowska, Itinerarium..., s. 283-285. Na takie opóźnienie w podróży królowej zwrócił uwage T. Lalik, Kaplica królewska i publiczne praktyki religijne rodziny Kazimierza Jagiellończyka, „Kwartalnik Historyczny” 1981, nr 88, s. 399, opóźnieniem tym tłumacząc nieobecność Elżbiety na mszy w Sandomierzu 26 czerwca, już jednak 28 czerwca w mszy brała udział cała rodzina; por. Rachunki królewskie z lat 1471-1472 i 1476-1478, wyd. S. Gawęda, Z. Perzanowski, A. Strzelecka, Wrocław-Kraków 1960, s. 236.

156 Rachunki królewskie..., s. 246-247; Długosz, lib. 12 (1462-1480), s. 416; ks. 12 (1462-1480), s. 431; Z. Wdowiszewski, Genealogia Jagiellonów..., s. 131; I. Skierska, Terminy koronacji, ślubów, chrztów i pogrzebów..., s. 221, przyp. 211.

157 Pomijam tu kwestie dat małżeństw córek i synów królewskich - to odrębny temat.

158 Z. Wdowiszewski, Genealogia Jagiellonów..., s. 128-129.

159 Ibidem, s. 132-133.

160 Ibidem, s. 132, że dzięki Decjuszowi jest znana data dzienna i miesięczna (13 listopada), kronikarz zostawił puste miejsce na rok, zob. Decjusz Jost Ludwik, De vestibus Polonorum liber, Liber I: De Jagellorum familie, k. XLIII, https://polona. $\mathrm{pl} /$ item/contenta-de-vetvstatibvs-polonorvm-liber-i-de-iagellonvm-familia-liber-ii-de,MTA1MDM5ODY1/47/\#item (dostęp: 1.12.2020). 
(Dopetnienie) nadmieniającej, że gdy Elżbieta wychodziła za mąż za księcia legnickiego Fryderyka II, miała 33 lata (ślub odbył się w 1515 r. $)^{161}$. Trudno zatem na podstawie tej hipotetycznej daty rocznej wyznaczać moment poczęcia królewny i łączyć go z trasami podróży królewskiej. Wiadomo, że Kazimierz Jagiellończyk i Elżbieta przebywali na Litwie od końca 1478 do jesieni 1484 r. (z krótką przerwą od 13 stycznia do 20 lutego 1484 r., gdy król był w Lublinie) ${ }^{162}$. Można zatem założyć, że ostatnie dziecko zostało poczęte na Litwie.

Królowa Elżbieta miała w 1483 r. około 47-48 lat, wkroczyła w okres przekwitania prowadzącego do ustania płodności. 4 marca 1484 r. zmarł drugi z synów królewskiej pary, królewicz Kazimierz $^{163}$, a 7 czerwca 1492 r. zmarł król Kazimierz Jagiellończyk, królowa przeżyła go o kilkanaście lat, zmarła 30 sierpnia 1505 r. ${ }^{164}$

$*$

Biorąc pod uwagę powyższą analizę, można zauważyć, że zwłaszcza w pierwszych latach małżeństwa królowa Elżbieta niemal nie rezygnowała $\mathrm{z}$ towarzyszenia mężowi w jego podróżach, nie udając się jednak na teren objęty bezpośrednio działaniami wojennymi. Nic zatem dziwnego, że pierwszy królewski potomek - przyszły król czeski i węgierski Władysław - przyszedł na świat co prawda na Wawelu, to jednak do jego poczęcia doszło poza Krakowem, w grę wchodzą takie miejscowości, jak: Łuków, Kazimierz Dolny, Radom, Opoczno czy wreszcie Piotrków. Nietrudno też zauważyć, że od momentu narodzin pierworodnego syna do kolejnej ciąży para królewska praktycznie się nie rozstawała, wspólnie opuszczając Kraków, podróżując i spędzając czas na Litwie. Córka Jadwiga została poczęta $\mathrm{w}$ trakcie zimowego pobytu na Litwie, najpewniej w Wilnie. Następne dzieci też były płodzone w czasie dłuższych pobytów królewskiej pary na Litwie: (zima) Kazimierz i (wiosna) Jan Olbracht. Syn Aleksander został poczęty najpewniej w Łęczycy, z kolei córka Zofia - w Brześciu Kujawskim. Trudno określić miejsce powołania na świat Elżbiety (1), stało się to w trasie

161 Rocznik świętokrzyski. Dopetnienie, wyd. R. Mauer [w:] MPH, t. 3, Lwów 1878, s. 89; Z. Wdowiszewski, Genealogia Jagiellonów..., s. 132-133.

162 T. Rombek, Otoczenie, Aneks Itinerarium, s. 285-286; G. Rutkowska, Itinerarium..., s. 290-311.

163 Z. Wdowiszewski, Genealogia Jagiellonów..., s. 101.

164 Ibidem, s. 92, 97. 
(w czasie któregoś z krótkich stacyjnych pobytów w Kłodawie, Łęczycy, Piotrkowie lub Parczewie). Syna Zygmunta królewska para poczęła w Łęczycy, zaś Fryderyka w Krakowie. Był pierwszym dzieckiem poczętym na Wawelu, podobnie jak jego młodsze siostry Elżbieta (2) i Barbara. Starsza od Barbary Anna powołana została na świat w trasie pomiędzy Lublinem a Nowym Miastem Korczynem.

Większość dzieci królewskiej pary przyszła na świat - podobnie jak ich najstarszy brat - na Wawelu, wyjątki stanowili: syn Zygmunt urodzony w Kozienicach (wiemy, że po prostu szukano schronienia przed zaraza), córka Anna urodzona w Nieszawie (niemal do końca królowa towarzyszyła małżonkowi w jego objazdach) oraz córka Barbara urodzona w Sandomierzu. Król był obecny przy urodzinach: Władysława, Jana Olbrachta, Zofii, Elżbiety (1), Zygmunta, Fryderyka, Elżbiety (2) i Barbary.

Znamy daty chrztu kilkorga królewskich dzieci - Władysława ochrzczono 4 kwietnia 1456 r. (ponad miesiąc po urodzeniu; gdy miał niecałe 2 miesiące, rodzice wyruszyli w podróż); Kazimierza - 5 listopada $1458 \mathrm{r}$. (ponad miesiąc od urodzin, czekano z chrzcinami na powrót króla; małżonkowie ruszyli w podróż po 3 miesiącach od jego urodzin); Jana Olbrachta - 3 dni po urodzeniu (30 grudnia 1459 r.); Zofia została ochrzczona tydzień po urodzeniu (rodzice udali się w podróż około 5 miesięcy po jej narodzinach). Król był zapewne obecny na chrzcinach: Elżbiety (1) w czerwcu 1465 r. (tydzień od urodzin), Zygmunta, Fryderyka (ochrzczonego 11 dni od narodzin), Elżbiety (2), z pewnością Barbary (od jej narodzin do chrztu minęło 11 dni).

Śledząc daty narodzin dzieci Kazimierza Jagiellończyka i Elżbiety, widzimy również, że w pierwszych latach małżeństwa przerwy pomiędzy porodami a kolejnymi ciążami nie były długie. W latach 1456 (pierwsze narodziny) -1461 do kolejnych ciąż dochodziło w następujących odstępach: druga ciąża po 9 miesiącach od pierwszego porodu, trzecia ciąża po $5-5 \frac{1}{2}$ miesiącach od drugiego porodu, czwarta ciąża po 7 miesiącach od trzeciego porodu; piąta ciąża około 11-12 miesięcy od czwartego porodu. Po narodzinach piątego dziecka (Aleksandra) nastapiła ponaddwuletnia przerwa, zanim królowa znowu zaszła w ciążę; do kolejnego poczęcia doszło we wrześniu 1463 r. Od urodzin szóstego dziecka do siódmej ciąży upłynęło 4-5 miesięcy; przerwa między siódmymi narodzinami a ósmą ciążą wyniosła około 10-11 miesięcy; od ósmych 
narodzin do dziewiątej ciąży upłynęło około 8 miesięcy. Od tego ósmego porodu (27 kwietnia 1468 r.) upłynęły 3 lata, zanim królowa była w ciąży (zapewne do tej przerwy przyczyniła się jej choroba, może poronienie). Dopiero około połowy sierpnia $1471 \mathrm{r}$. królowa po raz kolejny zaszła w ciążę. Po narodzinach dziesiątego dziecka (20 kwietnia 1472 r.) nastapiła ponadtrzyletnia przerwa. Królowa była w ciąży dopiero w czerwcu 1475 r., dziecko urodziło się w marcu 1476 r. i kolejne poczęcie miało miejsce mniej więcej półtora roku później. Nie możemy dywagować na temat daty i miejsca poczęcia ostatniej córki królewskiej, Elżbiety (3), nie znamy daty rocznej odnośnie do jej urodzin. Interwały pomiędzy porodami a kolejnymi poczęciami dobrze ilustruje poniższa tabela.

Tabela 1. Interwały pomiędzy porodami i kolejnymi ciążami królowej Elżbiety Rakuskiej

\begin{tabular}{|c|c|c|c|c|}
\hline Lp. & Data urodzin & $\begin{array}{l}\text { Przybliżona } \\
\text { data kolejnego } \\
\text { poczęcia }\end{array}$ & $\begin{array}{c}\text { Liczba } \\
\text { miesięcy } \\
\text { od urodzin } \\
\text { do ponownej } \\
\text { ciąży }\end{array}$ & Uwagi \\
\hline 1. & 1 marca 1456 & $\begin{array}{c}\text { styczeń/luty } \\
1457\end{array}$ & ok. 9 & - \\
\hline 2. & 21 września 1457 & $\begin{array}{c}\text { połowa lutego } \\
1458\end{array}$ & ok. 5 & - \\
\hline 3. & $\begin{array}{c}3 \text { października } \\
1458\end{array}$ & $\begin{array}{c}\text { początek/połowa } \\
\text { kwietnia } 1459\end{array}$ & ok. 7 & - \\
\hline 4. & 27 grudnia 1459 & $\begin{array}{c}\text { koniec listopada/ } \\
\text { pocz. grudnia } \\
1460\end{array}$ & ok. $11-12$ & - \\
\hline 5. & 3 sierpnia 1461 & wrzesień 1463 & ponad 24 & $\begin{array}{c}\text { może jakaś } \\
\text { choroba }\end{array}$ \\
\hline 6. & 6 maja 1464 & $\begin{array}{l}\text { październik/ } \\
\text { listopad } 1464\end{array}$ & ok. $4-5$ & - \\
\hline 7. & 9 czerwca 1465 & kwiecień 1466 & ok. $10-11$ & $\begin{array}{l}\text { dziecko } \\
\text { zmarło } \\
\text { po roku }\end{array}$ \\
\hline 8. & 1 stycznia 1467 & $\begin{array}{c}\text { sierpień/ } \\
\text { wrzesień } \\
1467\end{array}$ & ok. 8 & - \\
\hline 9. & 27 kwietnia 1468 & sierpień 1471 & ok. 28 & - \\
\hline
\end{tabular}




\begin{tabular}{|c|c|c|c|c|}
\hline 10. & 20 kwietnia 1472 & czerwiec 1475 & ponad 36 & $\begin{array}{c}\text { dziecko } \\
\text { zmarło } \\
\text { około 1480 }\end{array}$ \\
\hline 11. & 12 marca 1476 & listopad 1477 & 18 & - \\
\hline 12. & 15 lipca 1478 & - & - & $\begin{array}{c}\text { nie wia- } \\
\text { domo, kiedy } \\
\text { dokładnie } \\
\text { urodziło się } \\
13 . \text { dziecko } \\
\text { - ok. 1483 }\end{array}$ \\
\hline
\end{tabular}

Źródło: opracowanie własne.

Jak wynika z niniejszej pracy, sporo informacji o rodzinie Kazimierza Jagiellończyka można uzyskać, śledząc jego i Elżbiety itinerarium - temat będzie kontynuowany w odniesieniu już nie tylko do podróży, ale również innych aspektów związanych z tą para i jej potomstwem.

\author{
Abstract \\ On the Circumstances of the Births of Royal Children \\ in the Light of the Itineraries of Kazimierz Jagiellończyk \\ and Elżbieta Rakuska
}

On 10 February 1454, the Polish King, Kazimierz Jagiellończyk (born 1427) married Elżbieta Rakuska (born around 1436/1437), daughter of the German, Czech, and Hungarian king, Albrecht II Habsburg and Elizabeth of Luxemburg.

Kazimierz Jagiellończyk and Elżbieta had 13 children, 7 daughters (two of them - also called Elżbieta - died in early childhood and 6 sons. So, in total, 11 children survived into adulthood. The royal couple gave birth to children with a certain regularity, more or less every several months, especially in the first years of their marriage. It is well-known that Elżbieta accompanied Kazimierz Jagiellończyk on his journeys for many years. Research has revealed the itineraries of the King and his wife. This article analyzes these itineraries with regard to the details of the journey and the place of conception of individual royal children. The analysis reveals that, especially in the first years of the marriage, King Kazimierz Jagiellończyk spent a lot of time journeying between different places. This was not just a consequence of the custom (common then) of royal progresses, but also of the military situation. Queen 
Elżbieta did not give up the company of her husband on his journeys, although she did not venture into areas directly affected by warfare. So it is not surprising that the first royal offspring - the future Czech and Hungarian King Władysław - saw the light of day in Wawel Castle, but he was conceived outside Kraków. Possibilities include Łuków, Kazimierz Dolny, Radom, Opoczno, or, finally, Piotrków.

Nor is it difficult to see that from the moment of the birth of their first-born son to Elżbieta's next pregnancy, the royal pair were practically never parted, leaving Kraków together, travelling and spending time in Lithuania. Their daughter Jadwiga was conceived during a winter stay in Lithuania, most likely in Wilno. The next children were also conceived during the couple's long visits to Lithuania: Kazimierz in winter, and Jan Olbracht in spring. Most likely, their son Aleksander was conceived in Łęczyca. In turn Zofia was conceived in Breść Kujawski. It is difficult to fix the place where Elżbieta (1) was conceived; it happened while travelling, at the time of one of the couple's brief stops in Kłodawa, Łęczyca, Piotrków, or Parczew. Zygmunt was conceived in Łęczyca, and Fryderyk in Kraków. He was the first but not the only one of the royal children to be conceived in Wawel Castle; his sisters Elżbieta (2) and Barbara were conceived there too. Anna, older than Barbara, was conceived somewhere en route between Lublin and Nowe Miasto Korczyn.

Like their eldest brother, the majority of the royal children were born in Wawel Castle. Exceptions were: Zygmunt, born in Kozienice (in this case, we know that this was a result of a search for a place safe from plague), Anna, born in Nieszawa (almost to the birth, the Queen accompanied her husband on his current journey), and Barbara, born in Sandomierz. The King was present at the following births: of Władysław, Jan Olbracht, Zofia, Elżbieta (1), Zygmunt, Fryderyk, Elżbieta (2), and Barbara. We know the dates of the christenings of several of the children: Władysław - 4 April 1456 (more than a month after his birth; his parents set off on a journey when he was almost two months old); Kazimierz - 5 November 1458 (more than a month after his birth; the christening waited till the King returned; the royal couple set off on a journey three months after his birth); Jan Olbracht - christened three days after his birth (30 December); Zofia - christened a week after being born (her parents set off on a journey five months after her birth). The King was certainly present at the christenings of Elżbieta (1) in June 1465 (a week after her birth), Zygmunt, Fryderyk (christened eleven days after being born), Elżbieta (2), and Barbara (eleven days elapsed between her birth and her christening).

If we look at the bates of birth of the children of Kazimierz Jagiellończyk and Elżbieta, we also see that in the first few years the gaps between a birth and a subsequent pregnancy were quite short. 
Between 1456 (the first birth) and 1461, pregnancies occurred at the following intervals: the second pregnancy was nine months from the first birth; the third pregnancy was five to five and a half months after the second; the fourth was around seven months after the third birth; and the fifth pregnancy came eleven to twelve months after the fourth birth. After the birth of a fifth child (Aleksander), there was a gap of more than two years before the Queen's next pregnancy, a subsequent conception being in September 1463. From the birth of her sixth child to her seventh pregnancy there was an interval of four to five months; from the seventh birth to the eighth pregnancy there was an interval of around ten to eleven months; from the eighth birth to the ninth pregnancy, it was eight months. After this eighth birth (27 April 1468), it was three years before the Queen was pregnant again, this interval being most likely caused by illness (perhaps miscarriage). It was only around mid-September 1471 that the Queen was pregnant again. After giving birth to her tenth child (20 April 1472), there was a gap of more than three years. The Queen only became pregnant again in June 1475. The child was born in March 1476, and a further conception took place more or less eighteen months later. We cannot discuss the date and place of conception of the royal daughter Elżbieta (3); we do not have annual data relating to the date of her birth. 